Review

\title{
Opportunities and challenges in the use of coal fly ash for soil improvements - A review
}

\author{
Sabry M. Shaheen a , Peter S. Hooda ${ }^{\text {b, }}{ }^{*}$, Christos D. Tsadilas ${ }^{\mathrm{C}}$ \\ a Department of Soil and Water Sciences, Faculty of Agriculture, University of Kafrelsheikh, 33516 Kafr El-Sheikh, Egypt \\ ${ }^{\mathrm{b}}$ Centre for Earth and Environmental Science Research, Kingston University London, Kingston upon Thames KT1 2EE, UK

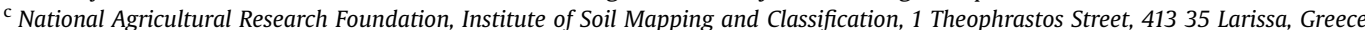

\section{A R T I C L E I N F O}

\section{Article history:}

Received 23 January 2014

Received in revised form 3 July 2014

Accepted 4 July 2014

Available online

\section{Keywords:}

Coal fly ash

Composition

Nutrients and contaminants

Soil properties

Soil improvement

Wastewater treatment

\begin{abstract}
A B S T R A C T
Coal fly ash (CFA), a by-product of coal combustion has been regarded as a problematic solid waste, mainly due to its potentially toxic trace elements, PTEs (e.g. $\mathrm{Cd}, \mathrm{Cr}, \mathrm{Ni}, \mathrm{Pb}$ ) and organic compounds (e.g. PCBs, PAHs) content. However, CFA is a useful source of essential plant nutrients (e.g. Ca, Mg, K, P, S, B, Fe, $\mathrm{Cu}$ and $\mathrm{Zn}$ ). Uncontrolled land disposal of CFA is likely to cause undesirable changes in soil conditions, including contamination with PTEs, PAHs and PCBs. Prudent CFA land application offers considerable opportunities, particularly for nutrient supplementation, $\mathrm{pH}$ correction and ameliorating soil physical conditions (soil compaction, water retention and drainage). Since CFA contains little or no N and organic carbon, and CFA-borne P is not readily plant available, a mixture of CFA and manure or sewage sludge (SS) is better suited than CFA alone. Additionally, land application of such a mixture can mitigate the mobility of SS-borne PTEs, which is known to increase following cessation of SS application. Research analysis further shows that application of alkaline CFA with or without other amendments can help remediate at least marginally metal contaminated soils by immobilisation of mobile metal forms.

CFA land application with SS or other source of organic carbon, $\mathrm{N}$ and $\mathrm{P}$ can help effectively reclaim/ restore mining-affected lands. Given the variability in the nature and composition of CFA ( $\mathrm{pH}$, macroand micro-nutrients) and that of soil ( $\mathrm{pH}$, texture and fertility), the choice of CFA (acidic or alkaline and its application rate) needs to consider the properties and problems of the soil. CFA can also be used as a low cost sorbent for the removal of organic and inorganic contaminants from wastewater streams; the disposal of spent CFA however can pose further challenges.

Problems in CFA use as a soil amendment occur when it results in undesirable change in soil pH, imbalance in nutrient supply, boron toxicity in plants, excess supply of sulphate and PTEs. These problems, however, are usually associated with excess or inappropriate CFA applications. The levels of PAHs and PCBs in CFA are generally low; their effects on soil biota, uptake by plants and soil persistence, however, need to be assessed. In spite of this, co-application of CFA with manure or SS to land enhances its effectiveness in soil improvements.
\end{abstract}

(c) 2014 Elsevier Ltd. All rights reserved.

\section{Introduction}

Coal has been and continues to be one of the largest sources of energy production in the world, showing a dramatic rise in its use, despite direct impacts of coal combustion on climate change and human health. In 2006, coal accounted for $25 \%$ of the world's primary energy supply, with its worldwide consumption totaling a record 3090 million tons of oil equivalent. China is the biggest

\footnotetext{
* Corresponding author. Tel.: +442084172155.

E-mail addresses: smshaheen1973@yahoo.com (S.M. Shaheen), p.hooda@ kingston.ac.uk (P.S. Hooda), tsadilas@lar.forthnet.gr (C.D. Tsadilas).
}

consumer of coal, accounting for about $39 \%$ of the total world coal consumption in 2006, followed by the United States (18\%), the European Union (10\%) and India (8\%) (Vom Berg, 1998; Feuerborn, 2011).

Globally, coal fly ash (CFA) generated in huge quantities from coal fired power plants, is a problematic solid waste (Skousen et al., 2013; Ram and Masto, 2014). Most estimates in the current literature put annual global CFA production somewhere in the region of 500 million tons (Ahmaruzzaman, 2010). These estimates, however, are based on at least 10 years old data. Over the intervening period coal consumption has already increased by $50 \%$, largely due to the economic growth in China (International Energy Statistics, 2011). Taking this into account, a more up to date estimate would mean 
that globally about 750 million tons of CFA is generated annually. Coal fly ash production and utilization data for 2005 (Pandey and Singh, 2010) show that India generates the greatest amount of CFA (118 million tons/year), followed by China (100 million tons/ year), the USA (75 million tons/year), Germany (40 million tons/ year), the UK (15 million tons/year), while Denmark, Italy and the Netherlands generate smaller CFA amounts (2 million tons/year). However, India utilizes a relatively smaller percentage (38\%) of the CFA produced compared to other countries e.g., China (45\%), the USA (65\%), Germany (85\%), the UK (50\%) while Denmark, Italy and the Netherlands utilize $100 \%$ of their CFA production (Pandey and Singh, 2010). The relatively lower amount of CFA utilization in India (mainly in construction industry) is due to unavailability of appropriate cost-effective technologies (Bhattacharjee and Kandpal, 2002; Dhadse et al., 2008).

Clearly a significant proportion of the annual production of CFA must be disposed of especially in the highest production countries such as India, China, and the USA. Traditionally this has been achieved by diverting the ash to landfills which incurs a landfill tax or by storing it in ash lagoons. These large lagoons have been known to breach, causing environmental problems (Dewan, 2008). Environmental concerns and increasingly stringent regulations are gradually increasing the cost of CFA disposal by landfilling (Haynes, 2009). The problem of CFA disposal is expected to get worse as the demand for energy grows.

Current forecasts predict that the next two decades will see the installation of the same amount of power generation capacity as that installed over the whole of the 20th century. Part of this increase in demand is likely to be met by renewable energy sources; however, due to its abundance in energy intensive countries such as China and India, coal is likely to become an increasingly dominant fuel for power generation (Lior, 2010). Clearly the huge quantity of CFA produced annually not only poses serious environmental concerns but also requires large areas of land for its storage and disposal. Thus, appropriate measures for its safe disposal and means of utilization are necessary for sustainable management of this waste (Singh et al., 2010). So far, two distinct alternatives CFA disposal options have been used i.e. its utilization in construction materials and land application as a soil amendment. In the first case, CFA is either used as raw material in the production of cement clinker or is blended with cement. Coal fly ash is used as the main component in blended cements, as a sand substitute in manufacturing of low strength materials, for foundation support and backfilling excavations, and for filling abandoned tunnels, as well as numerous others construction works (Siddique, 2010; Skousen et al., 2013). The other important alternative use of CFA is its land application, utilizing its properties as a soil amendment and possibly as a source of nutrient supplementation. Coal fly ash, however, can contain significant amounts of potentially toxic trace elements (PTEs) and other chemicals, presenting challenges to its land application for soil improvement.

Utilization of CFA as an ameliorant for improving soil quality has received a great deal of attention over the past four decades. Several extensive reviews on recycling of CFA have been conducted in recent years (e. g., Jala and Goyal, 2006; Basu et al., 2009; Malik and Thapliyal, 2009; Blissett and Rowson, 2012; Yunusa et al., 2012; Skousen et al., 2013; Ram and Masto, 2014). However, they have focused on the multi-component utilization of CFA with a limited coverage of the environmental challenges. A review by Malik and Thapliyal (2009) analyzed the general uses of CFA in various industries with only a brief coverage of its use in the agricultural sector. Blissett and Rowson (2012) focused on the multi-component utilization of CFA (agriculture, glass and ceramics manufacturing, zeolites and mesoporous materials productions, geopolymers synthesis, and use as catalysts and catalyst supports). Yunusa et al.
(2012) considered how CFA can be strategically used to ameliorate specific soil constraints to crop production but focussing only on soil salinity, alkalinity and mainly from economic and regulatory considerations. However, none of these previous reviews critically analyzed all of the major relevant environmental issues, which include practices and problems considerations in devising sustainable use of CFA as a soil amendment. This article reviews the current status of the CFA disposal practices and problems, particularly focussing on its use as a soil amendment and the challenges it presents.

\section{Physical and chemical properties of CFA}

The mineralogical, physical and chemical properties of CFA depend on the nature and properties of the parent coal and conditions under which they were produced, and they have been extensively reviewed (e.g., Adriano et al., 1980; Elseewi et al., 1980a). The composition and properties of CFA can also vary considerably, depending on the boiler type and the gas emission control system (Skousen et al., 2013). It is these properties which together determine the usefulness of CFA in soil improvement.

\subsection{Physical properties}

Coal fly ash is comprised of very fine particles, with an average diameter $<10 \mu \mathrm{m}$, aggregated into spherical particles of 0.01-100 $\mu \mathrm{m}$ sizes which are hollow spheres (cenospheres) filled with smaller amorphous particles or crystals (pelospheres) (Jala and Goyal, 2006). These cenospheres make CFA particles easily airborne (El-Mogazi et al., 1988). Coal fly ash generally has a silt loam texture, with 65-90\% of the particles having diameters of less than $0.010 \mathrm{~mm}$ (Chang et al., 1977; Pandey and Singh, 2010; Nyambura et al., 2011). Ash from bituminous coal is usually finer than that produced from lignite combustion (Tolle and Arthrur, 1983; Dudas and Warren, 1987).

Due to the small size of CFA particles (cenospheres) and the pelospheres, CFA has a large specific surface area ranging from 2500 to $4000 \mathrm{~cm}^{2} \mathrm{~g}^{-1}$, as measured by the Blaime method (Alonso and Wesche, 1991); consequently CFA has a high sorption capacity. Because of this, CFA is used as a sorbent for flue gas cleaning from sulphur components, NOx, gaseous organics such as toluene vapours and is also used for removal from wastewater of several toxic metal ions, such as $\mathrm{Cu}, \mathrm{Pb}, \mathrm{Cd}, \mathrm{Ni}, \mathrm{Zn}, \mathrm{Cr}, \mathrm{Hg}$, As and $\mathrm{Cs}$ and inorganic anions such as, fluoride and boron. In addition CFA sorbs considerable amounts of dyes and pigments and has thus been used for their removal from aqueous waste streams (El-Mogazi et al., 1988; Alonso and Wesche, 1991). The specific gravity of CFA varies from 2.1 to $2.6 \mathrm{~g} \mathrm{~cm}^{-3}$ and it has a low to medium bulk density, ranging from 1 to $1.8 \mathrm{~g} \mathrm{~cm}^{-3}$. Its moisture retention capacity ranges from $6.1 \%$ at 15 bars to $13.4 \%$ at $1 / 3$ bar (El-Mogazi et al., 1988). The colour of CFA ranges from water-white to yellow-orange to deep red or brown to opaque, depending mainly on the $\mathrm{Fe}_{2} \mathrm{O}_{3}$ and carbon contents. The un-burnt coal content, corresponding to loss on ignition, ranging from 0.5 to $12 \%$ is responsible for the black or grey appearance of CFA. The presence of high amounts of $\mathrm{Fe}_{2} \mathrm{O}_{3}$ gives CFA dark colour (Alonso and Wesche, 1991).

\subsection{Chemical properties}

The chemical characteristics of CFA depend largely on geological factors related to the coal deposits and on different operating conditions/practices employed at the power plants. Thus, CFA from every coal-fired plant has its own chemical characteristics. The main constituents of CFA are silica, alumina and iron oxides, with varying amounts of carbon, calcium, magnesium, and sulphur. 
Coal fly ashes (CFAs) are usually grouped into two classes, i.e. Class F produced from anthracite, bituminous and sub-bituminous coals containing less than $7 \% \mathrm{CaO}$, and Class $\mathrm{C}$ produced from lignite coal containing more liming material, up to $30 \%$ (Wang and $\mathrm{Wu}$, 2006). The $\mathrm{pH}$ of CFA ranges between 4.5 and 13.25, depending largely on the sulphur and $\mathrm{CaO}$ contents of the parent coal (Riehl et al., 2010). CFAs produced from coals containing high amounts of anthracite (usually contains high amounts of sulphur, S) are acidic while that produced from lignite (usually lower in $S$ and higher in Ca) are alkaline. Generally the coal from India is low in S but high in ash content (40\%) compared to the coal produced in the US which usually is rich in S (2\%) but contains only 5-10\% ash (Jala and Goyal, 2006; Singh et al., 2010). The S content of CFA usually varies from 0.1 to $1.5 \%$ while that of soils ranges from 0.01 to $2 \%$ (Page et al., 1979; Hodgson et al., 1982; Warren and Dudas, 1984). The electrical conductivity (EC) of CFA in water extracts varies widely (Page et al., 1979; Aitken et al., 1984).

\subsubsection{Elemental composition of CFA}

The elemental composition of CFAs varies widely; however, they usually contain considerable amounts of plant nutrients except $\mathrm{N}$ when compared to soils (Table 1). Nitrogen in CFA is present in negligible quantities since it is oxidized during the combustion process.

Phosphorus in CFA can vary widely (0.0002-1.08\%; Table 1$)$, which in many situations is quite high compared to soils (0.005-0.2\%; Table 1). However, P in CFA is often in forms that are not readily plant available (Page et al., 1979; Adriano et al., 1980; Jala and Goyal, 2006). In comparison with CFA, biomass ash contains high concentrations of $P$ that range from $0.01 \%$ in bagasse ash (Jamil et al., 2004) to $10.4 \%$ in cereal biomass ash (Eichler et al., 2008; Schiemenz and Eichler-Lobermann, 2010; Schiemenz et al., 2011). Schiemenz et al. (2011) reported that the water soluble P in biomass ash is low; however, about $80 \%$ of $\mathrm{P}$ is soluble in citric acid, which is potentially bioavailable. Generally, the P fertilizing effect of biomass ashes is comparable to that of highly soluble P fertilizers such as triple superphosphate (Schiemenz et al., 2011).

Concentrations of $\mathrm{P}$ in wood ashes are also relatively higher than CFA and range between 0.90 and 1.70\% (Demeyer et al., 2001; Saarsalmi et al., 2001; Hytönen, 2003). However, similar to CFA, P in wood ash remains relatively insoluble. In general, $\mathrm{P}$ is the least plant available major nutrient in wood ash (Demeyer et al., 2001). In short period incubation studies, Ohno (1992) found that $<1 \%$ of the added wood ash-P was water-soluble. Thus, there may be some similarities between P availability in wood ash and CFA. This may be at least partly due to the similarity in their alkalinity and the composition. The alkalinity or acidity neutralizing capacity of wood ash is high ( $\mathrm{pH}=8.9-13.5$; Demeyer et al., 2001). Phosphorus in wood and CFAs is most probably occluded in aluminosilicates or in the form of weakly soluble aluminum phosphate (Ohno and Erich, 1990; Erich, 1991; Erich and Ohno, 1992). The release of nutrients from wood ash and CFA in soil and their plant availability is complicated. Firstly, wood ash and CFA contain several cations and each of these cations forms oxides, hydroxides, carbonates and bicarbonates (Erich and Ohno, 1992; Ulery et al., 1993) which dissolve at different rates. Secondly, soil nutrient availability is determined by a combination of three factors: (i) nutrient addition from the ash; (ii) shifts in $\mathrm{pH}$-dependent soil chemical equilibria; and (iii) the extent of change in soil microbial activity. Thus, CFA and wood ash do not seem to be optimal sources of plant available $\mathrm{P}$, particularly when compared with biomass ash (Schiemenz and Eichler-Lobermann, 2010).

Calcium, $\mathrm{K}$, and $\mathrm{Mg}$ are present in CFAs in similar or higher concentrations compared to soils and mostly in forms that are readily plant available. Trace elements (TEs) which are essential in plant growth such as $\mathrm{Cu}, \mathrm{Fe}, \mathrm{Mn}, \mathrm{Mo}, \mathrm{Zn}, \mathrm{B}$ occur in CFA in quantities similar or higher than those found in soils, constituting a considerable source of TEs for plants (Table 1), particularly in soils with their limited supply. However, plant availability of such TEs can vary greatly, depending mostly on soil pH (Page et al., 1979; Adriano et al., 1980).

Table 1

Major and trace elements in coal fly ash (CFA) and soils.

\begin{tabular}{|c|c|c|c|c|c|c|c|c|}
\hline \multirow[t]{2}{*}{ Element } & \multicolumn{7}{|l|}{ Coal fly ash } & \multirow{2}{*}{$\begin{array}{l}\text { Soil } \\
\text { Page et al. } \\
(1979)\end{array}$} \\
\hline & $\begin{array}{l}\text { Page et al. } \\
\text { (1979) }\end{array}$ & $\begin{array}{l}\text { Adriano et al. } \\
\text { (1980) }\end{array}$ & $\begin{array}{l}\text { Jala and Goyal } \\
(2006)\end{array}$ & $\begin{array}{l}\text { Tripathi et al. } \\
\text { (2009) }\end{array}$ & $\begin{array}{l}\text { Pandey et al. } \\
(2009)\end{array}$ & $\begin{array}{l}\text { Riehl et al. } \\
\text { (2010) }\end{array}$ & $\begin{array}{l}\text { Lopareva-Pohu et al. } \\
\text { (2011) }\end{array}$ & \\
\hline \multicolumn{9}{|c|}{ Major elements, $\mathrm{g} \mathrm{kg}^{-1}$} \\
\hline $\mathrm{Al}$ & $1-17.3$ & $-{ }^{a}$ & 312 & - & 4.8 & 108.5 & 0.47 & $40-300$ \\
\hline $\mathrm{Ca}$ & $1.1-222$ & 5.4 & 34 & 0.029 & - & 86.4 & 1.84 & $7-500$ \\
\hline $\mathrm{Fe}$ & $10-290$ & 16 & 68 & 0.0032 & 4 & 36.6 & 0.31 & $7-550$ \\
\hline $\mathrm{K}$ & $1.5-35$ & 1.8 & 10.8 & 0.072 & - & 24.5 & 0.0021 & $0.4-30$ \\
\hline $\mathrm{Mg}$ & $0.4-76$ & 1.2 & 1.4 & 0.017 & - & 11.5 & 0.019 & $0.6-6$ \\
\hline $\mathrm{P}$ & $0.4-8$ & 0.5 & 10.8 & 0.0027 & 1.1 & 2.1 & 0.0024 & $0.05-2$ \\
\hline$S$ & $1-15$ & 20 & 0.02 & 0.058 & - & 2 & 0.013 & $0.1-2$ \\
\hline \multicolumn{9}{|c|}{ Trace elements, $\mathrm{mg} \mathrm{kg}^{-1}$} \\
\hline As & $2.3-6300$ & - & 6.2 & $\mathrm{BLD}^{\mathrm{b}}$ & - & - & 20.4 & $0.1-40$ \\
\hline B & $10-618$ & 50 & - & - & 28.9 & - & 0.40 & $2-100$ \\
\hline $\mathrm{Cd}$ & $0.7-130$ & 1.3 & 1.9 & 13.4 & 42.5 & 0.03 & - & $0.01-7$ \\
\hline Co & $7-520$ & 7 & 58 & 21.1 & - & 26 & 17 & $1-40$ \\
\hline $\mathrm{Cr}$ & $10-1000$ & 15 & 330 & 38.2 & 40.3 & 148 & 46 & $5-3000$ \\
\hline $\mathrm{Cu}$ & $14-2800$ & 19 & 0.002 & 65.8 & 58.4 & 57 & 38 & $2-100$ \\
\hline $\mathrm{Hg}$ & $0.02-1.0$ & 0.18 & - & BLD & - & & 0.40 & - \\
\hline $\mathrm{Mn}$ & $58-3000$ & 100 & 739 & 0.006 & 69.3 & 679 & 418 & $100-4000$ \\
\hline Mo & $7-160$ & 3.0 & 4.0 & - & 33.3 & 4.2 & - & $0.2-5.0$ \\
\hline $\mathrm{Ni}$ & $6.3-4300$ & 15 & 13 & 44.2 & 204.8 & 88 & 48 & $10-1000$ \\
\hline $\mathrm{Pb}$ & $3.1-5000$ & 16 & 35 & 20.0 & 40.2 & 97 & 39 & $2-100$ \\
\hline V & - & 20 & - & - & - & 182 & - & $50-1000$ \\
\hline Se & $0.2-134$ & 3 & 3.6 & - & - & - & - & $10-25$ \\
\hline $\mathrm{Zn}$ & $10-3500$ & 39 & 79 & 57.7 & 82.3 & 167 & 85 & $10-300$ \\
\hline
\end{tabular}


Besides the elements that are essential for plant growth, CFA also contains significant quantities of PTEs (Table 1). Between them, of main concern are $\mathrm{Cd}, \mathrm{Pb}, \mathrm{Ni}, \mathrm{Se}$, and $\mathrm{Hg}$ which may enter the food chain. However, the enrichment of soils with PTEs is considered negligible because of their generally small level of additions (unless CFA is applied in excessive amounts), and their usually lower solubility keeps them in less mobile forms. Elements that are restrictive to agronomic use of CFA are mostly Mo, Se, and B (Tolle and Arthrur, 1983; Aitken et al., 1984; Querol et al., 1995), as they can be present in large amounts when compared to their general soil levels and their requirements for plant growth. A recent study of coal and CFA samples, using particle induced X-ray emission spectroscopic technique confirmed that $\mathrm{K}, \mathrm{Ca}$, Ti and Fe were present as major elements, whereas, other elements, e.g. V, Cr, Mn, Co, $\mathrm{Ni}, \mathrm{Cu}, \mathrm{Zn}, \mathrm{As}, \mathrm{Se}, \mathrm{Rb}, \mathrm{Sr}$ and $\mathrm{Pb}$ were present in trace amounts (Patra et al., 2012a). Despite the chemical composition of CFA (Table 1) being highly variable, the material has the potential for its use for soil improvement, provided used prudently.

\subsubsection{Organic pollutants in CFA - sources and concentrations}

CFA also contains organic constituents of potential environmental concern. The organic matter of coals is generally comprised of two complementary constituents: (a) the principal component is a macromolecular, insoluble phase consisting of condensed aromatic and hydroaromatic units, and (b) a molecular phase of compounds of low to medium molecular mass, mostly soluble in organic solvents, assumed to contain variable levels of aliphatic hydrocarbons, polycyclic aromatic and hydroaromatic hydrocarbons, hydroxylated polycyclic aromatic compounds and heterocyclic compounds (Mastral et al., 1995; Liu et al., 2000; Pisupati et al., 2000; Sahu et al., 2004). During coal combustion, organic remains are released, which through cyclisation or radical condensation reactions result in the formation of polycyclic aromatic hydrocarbons (PAHs), and the combustion of carbon in the presence of chloro fragments leads to the formation of polychlorinated biphenyls (PCBs). The main source of concern with PAHs and PCBs is that some members of these groups of chemicals are known mutagens and carcinogens (USEPA, 1992). The PAHs formed can be emitted as gases or as fine particulate matter (Mastral et al., 2000). Additionally, PAHs originally emitted in the gaseous phase during combustion can be subsequently adsorbed onto the CFA generated (Liu et al., 2000). The combustion processes have been reported as possible sources of PCBs, which may be formed when a carbon source and chlorine are combusted together. Highly chlorinated PCBs can stick tightly to airborne particulates and can get adsorbed onto the CFA particles, eventually being released to the atmosphere through smokestack. The low chlorinated PCBs are more reactive in the atmosphere and can be degraded to carboxylic acids in the presence of highly reactive molecules (Sahu et al., 2009).

Only a few studies have considered characterization of organic constituents in CFA. Studies carried out indicate that various complex organic molecules, such as PAHs, PCBs, polychlorinated dibenzo-p-dioxins (PCDDs), polychlorinated dibenzofurans (PCDFs), and dimethyl and monomethyl sulphate are present in CFA (Clement and Karasek, 1982; Gohda et al., 1993; Bagnoli et al., 2005). Sahu et al. (2009) investigated the characterization and quantification of PAHs and PCBs in CFAs generated in five power stations from different parts of India. They reported that lower molecular weight PAHs were predominant in the CFA samples examined. The total PAHs in the CFA samples were found to range between 0.043 and $0.936 \mathrm{mg} \mathrm{kg}^{-1}$. The concentration of Benzo(a) Pyrene, which is the most potent carcinogenic and mutagenic PAH, varied between $0.82 \mu \mathrm{g} \mathrm{kg}^{-1}$ and $18.14 \mu \mathrm{g} \mathrm{kg}^{-1}$, with a mean concentration of $9.02 \mu \mathrm{g} \mathrm{kg}^{-1}$ (Sahu et al., 2009). These authors further noted that higher levels of PAHs in the CFA were due the higher amount of organic matter in the feed coal. Also, other studies show that lower molecular weight PAHs are the major contributors to the total PAHs in CFA from pulverized coal power station (Mastral and Callen, 2000). In a study on PAHs emission from coal combustion, fluorene (a PAH compound) was reported as the main contributor to total PAHs at a wide range of combustion temperatures (Rose and Rippey, 2002).

The emission patterns of PCBs as determined by their levels in CFAs are dominated by the tetra substituted congener PCB-77 (Sahu et al., 2009). Among the PCB congeners, CB-77 has higher toxicity, the concentration of which in the CFA samples were found to range between 4.58 and $104.98 \mu \mathrm{g} \mathrm{kg}^{-1}$, with a mean value of $62.53 \mu \mathrm{g} \mathrm{kg}^{-1}$ (Sahu et al., 2009). Trichlorinated PCBs are generally low; this can be due to their high reactivity in the atmosphere and degradation to carboxylic acids in the presence of highly reactive molecules. Moreover, the concentrations of highly chlorinated PCBs were nearly constant in all the CFA samples analyzed (Sahu et al., 2009). The total PCBs in the CFA samples ranged between 7.3 and $178.7 \mu \mathrm{g} \mathrm{kg}^{-1}$ (Sahu et al., 2009). PCBs tend to bind to particulates than being in gaseous states (Sloss and Smith, 1993). Thus, the concentration of PCBs in CFA is generally significant, though less than that of PAHs (Sloss and Smith, 1993; Sahu et al., 2009).

A comparison of PAH and PCB inventories in CFA from different thermal power stations showed that the total PCB levels in individual plants do not vary as significantly as PAHs (Sakai, 1999; Sahu et al., 2009). Studies carried out on PAH emissions from various feed materials show that the PAH emissions largely depend on the properties of the fuel (Sahu et al., 2009). The tendency of different materials to form PAH can be ranked as follows (assuming all other variables are kept constant): Coal > lignite > wood > waste oil $>$ residual oil $>$ distillate oil (Sakai, 1999). This ranking shows a decline in the tendency of PAH formation with the decrease in ash content of the feed materials. The emission of PAHs from coal fired thermal power stations thus depends on the feed coal properties (Sakai, 1999). Various mechanisms are presumed to account for the emission of PAHs from combustion processes. The presence of PAHs in the emissions could be because they are present in the feed material itself which can pass through the combustion system without being destroyed (Sloss and Smith, 1993). Also, there could be reformation of ring structures from fragments and precursors that can lead to the formation of PAHs in the combustion zone, or downstream, at temperatures around $700{ }^{\circ} \mathrm{C}$; and there could also be a "de novo" synthesis of PAHs via oligomerization and cyclisation of acetylenes which are formed as a result of incomplete combustion (Sloss and Smith, 1993). Additionally, the formation and release of PAH is also strongly dependent on the combustion temperature, the residence time in the combustion zone, turbulence, the air to fuel ratio and the presentation of the feed material (Sloss and Smith, 1993; Neil and Rippey, 2002; Sahu et al., 2009). It is thus obvious to get a distinct and different pattern of PAHs in the CFA from different power plants.

There is conflicting information on the pattern of PCBs in CFA. Also, there are differences in the literature on the mechanism of PCB formation during combustion. Many of the researchers, who observed the same pattern of PCBs in CFA to that of the commercial aroclor mixtures, believe that the PCBs are present in the coal itself and come directly from the feed coal into CFA (Sahu et al., 2009). Fangmark et al. (1995) and Callén et al. (2007) concluded that there could be a "de novo" formation of PCBs in the combustion process from carbon and chlorine in the presence of particulate ash mainly in the post combustion zone. The pattern of PCBs in CFA will therefore largely vary according to different operating conditions and the difference in organic as well as chloro content of the feed coal in different power plants. 
Whilst CFAs are expected to contain organic pollutants, PAHs and PCBs, it is important that these need to be seen in the wider context, i.e. their levels in other wastes. Comparisons of organic pollutants in sewage sludge (SS) and CFA often show that total PAH levels are relatively greater in SS than in CFA (Sahu et al., 2009), with their SS levels ranging from non-detected to $199 \mu \mathrm{g} \mathrm{kg}^{-1}$ (Frost et al., 1993; Schnaak et al., 1997; Harrison et al., 2006). Moreover, PCB concentrations in SS can be as much as 5 times greater than those in CFA (Sahu et al., 2009) and have been found to range from non-detectable to $765 \mu \mathrm{g} \mathrm{kg}^{-1}$ SS (Chevreuil et al., 1990; Frost et al., 1993; Wilson et al., 1997; Berset and Etter-Holzer, 1999; Lazzari et al., 2000; Stevens et al., 2003; Eljarrat et al., 2003; Blanchard et al., 2004; Katsoyiannis and Samara, 2004; Harrison et al., 2006). Thus, it appears that PAHs and PCBs in CFA are generally lower than SS; however, CFA-borne PAHs and PCBs can pose significant risk to the wider environment, especially in situations where CFA is land applied in excessive amounts. There is also a need to assess the effects of CFA-borne PHAs and PCBs on soil biota, uptake by plants and their soil persistence. To our knowledge these issues have not received much scientific attention.

\section{Influence of CFA application on soil properties}

\subsection{Physical properties}

Land application of CFA can improve soils with poor physical properties, including texture, bulk density and water holding capacity. Coarse-textured soils can be amended with CFA to increase the silt- and sand-sized fractions, which help in aggregation, infiltration and soil water-storage (Skousen et al., 2013). However, the extent of changes in soil physical conditions would depend on the amount applied and physical properties of the soil and CFA. For example, Adriano and Weber (2001) found that CFA application had no effect on the soil bulk density, and attributed this finding to the texture and density of the CFA used being similar to that of the most agricultural soils $\left(2.16 \mathrm{~g} \mathrm{~cm}^{-1}\right)$. However, the CFA application did increase the plant available water content and water holding capacity of the soil (Adriano and Weber, 2001). This was attributed to the large surface area of the spherical-shaped CFA particles which increases soil microporosity, thus, enhancing soil water holding capacity. It should however be noted that improvement in the water holding capacity and plant available water content became significant only at very high CFA application rates (560 and $1120 \mathrm{t} \mathrm{ha}^{-1}$ respectively). Such large amounts of CFA application are likely to induce undesirable changes in other soil properties. Similar improvements in soil water holding capacity due to CFA application were found in other studies, as referred in Jala and Goyal (2006) and Singh et al. (2010). In contrast to Adriano and Weber (2001), several other studies reported that CFA addition decreases soil bulk density (Adriano et al., 1980; Singh et al., 2010), possibly in situations where the bulk density of CFA was lower than that of the soil and the amount applied was large.

Coal fly ash application can affect soil hydraulic conductivity, depending on soil type and quantity of CFA applied. At low rates CFA improves soil hydraulic conductivity (Adriano et al., 1980). Pathan et al. (2003) found that application of fine textured acidic CFA to coarse textured soils reduced drainage and thus increased water holding capacity. It would thus appear that the use of CFA can improve soil moisture retention and its plant availability. This, however, may not be possible without excessive rates of CFA application, which can cause undesirable consequences, e.g. excess amounts of PTEs. Nonetheless, the use of CFA as a soil amendment has the potential to improve soil physical conditions when applied in appropriate amounts.

\subsection{Chemical properties}

The effect of CFA application on soil chemical properties depends on the chemical composition of CFA. Coal fly ash can change soil $\mathrm{pH}$ in both directions i.e. decrease or increase, depending on the CFA characteristics and the degree of weathering (ageing). Coal fly ashes produced from coal containing high amounts of sulphur are acidic in reaction; land application of such ashes is likely to decrease soil $\mathrm{pH}$, particularly in soils with neutral to alkaline reactions (Pathan et al., 2003). Land application of weathered alkaline CFA is likely to increase soil pH. Alkaline CFA can be used to neutralize acidity and raise $\mathrm{pH}$ of acidic soils (Skousen et al., 2013). For example, the application of weathered alkaline CFA ( $\mathrm{pH}$ $8.5-8.9$ ) to an acidic soil increased its $\mathrm{pH}$ from 4.7 to 7.7 , proportionally to the CFA application rate (Matsi and Keramidas, 1999). The highest $\mathrm{pH}$ value was obtained with a rate of $50 \mathrm{~g} \mathrm{CFA} \mathrm{kg}^{-1}$ soil (5\%). Similar increases in soil pH after CFA application have also been reported in other studies (e.g., Tsadilas et al., 2009a; Shaheen and Tsadilas, 2010, 2013; Lopareva-Pohu et al., 2011). Appropriately selected CFA (alkaline for acidic soils and acidic for alkaline soils) can thus be used for soil $\mathrm{pH}$ correction purposes.

Electrical conductivity (EC) is another important property of agricultural soils in terms of its effect on plant growth. Since CFA is rich in soluble salts, usually its soil application increases soil EC (Matsi and Keramidas, 1999; Singh et al., 2010; Tsadilas et al., 2009a,b), which can be undesirable. However, in some cases soil EC decreased following CFA application (e.g. Sinha and Gupta, 2005; Gupta and Sinha, 2009). The decrease in soil EC in these cases was attributed to the precipitation of the soluble compounds in the ash amended soils due to concurrent significant increase in the soil $\mathrm{pH}$. In general it can be said that CFA application to soils is not likely to increase EC to harmful levels for most agricultural crops, unless CFA is applied in excessive amounts.

Soil boron (B) can be elevated following CFA application (Tsadilas et al., 2002; Matsi and Keramidas, 1999). Boron is usually present in considerable amounts in CFAs (Table 1). The increase in B plant-availability, however, usually remains at levels which are nontoxic to agricultural crops (Matsi and Keramidas, 1999). This is probably due to the fact that water soluble B in CFA usually undergoes gradual decrease with the time of storage or its land application (Adriano et al., 1980).

Since CFA contains sulphur (S), it can be applied to S-deficient soils and when applied in sufficient amounts it can help correct Sdeficiency in plants (Chang et al., 1977). Significant increased supply of all the metallic nutrients has been noted following CFA soil application (Jala and Goyal, 2006; Gupta and Sinha, 2009; Singh et al., 2010), with the exception of $\mathrm{Zn}$ in some cases. In fact, Adriano et al. (1978) reported that CFA soil application caused $\mathrm{Zn}$ deficiency symptoms in plants grown in CFA amended soils, possibly due to concurrent increased soil $\mathrm{pH}$ which decreased $\mathrm{Zn}$ solubility. However, when applied in appropriate amounts and considering the likely changes in soil $\mathrm{pH}$ (depending on the $\mathrm{pH}$ of the soil and CFA) CFA can be a useful source of micronutrient supplementation.

Coal fly ash often contains appreciable amounts of many PTEs (Table 1). Generally the finer the CFA texture the higher the amounts of PTEs they contain (Adriano et al., 1980). Contamination of soils and groundwater with PTEs is the main concern when CFA is disposed of on land. CFA soil application generally increases the total content of PTEs, as reported in several studies (e.g., Jala and Goyal, 2006; Gupta and Sinha, 2009; Ahmaruzzaman, 2010), and also increases their leaching potential (Jala and Goyal, 2006). However, the bioavailability and leaching potential of CFA-borne PTEs may not increase significantly or may decrease with time especially in the cases of alkaline CFA due to the expected increase 
Table 2

Impact of CFA application rate on plant growth and yield.

\begin{tabular}{|c|c|c|c|c|c|}
\hline \multirow[t]{2}{*}{ Type of plant } & \multirow[t]{2}{*}{ CFA application rate ${ }^{a}$} & \multicolumn{2}{|l|}{ Yield } & \multirow[t]{2}{*}{ CFA rate ${ }^{\mathrm{d}}$ compared } & \multirow[t]{2}{*}{ References } \\
\hline & & Control & CFA Treatment & & \\
\hline Rice & $0,2-8 \%(w / w)^{b}$ & $25.3 \mathrm{~g} \mathrm{pot}^{-1}$ & 27.7 & 4 & Sikka and Kansal (1995) \\
\hline Wheat & & $3.7 \mathrm{~g} \mathrm{pot}^{-1}$ & 3.8 & 2 & \\
\hline Tomato & $0,10-100 \%$ & $4.5 \mathrm{~g} \mathrm{pot}^{-1}$ & 9.5 & 60 & Khan and Khan (1996) \\
\hline Faba bean & $0,10-30 \%$ & $3.0 \mathrm{~g} \mathrm{pot}^{-1}$ & 4.2 & 10 & Singh et al. (1997) \\
\hline Ryegrass & $0,0.5-5 \%$ & $15.8 \mathrm{~g} \mathrm{pot}^{-1}$ & 28.5 & 5 & Matsi and Keramidas (1999) \\
\hline Rice shoot & $0,20-100 \%$ & 9.7 g plant $^{-1}$ & 10.8 & 40 & Singh and Siddiqui (2003) \\
\hline Rice grain & & $29.3 \mathrm{~g}^{\mathrm{c}}$ & 30.3 & & \\
\hline Sesbania cannabina & $0,10-100 \%$ & $22 \mathrm{~g} \mathrm{plant}^{-1}$ & 35 & 25 & Sinha and Gupta (2005) \\
\hline Rice & $0,40-120 \mathrm{t} \mathrm{ha}^{-1}$ & $4.0 \mathrm{tha}^{-1}$ & 5.6 & 80 & Lee et al. (2006) \\
\hline Rice straw & $0,10-100 \%$ & $9.5 \mathrm{~g}$ plant -1 & 18.5 & 25 & Dwivedi et al. (2007) \\
\hline Rice seed & & 6.5 & 13.6 & & \\
\hline \multirow[t]{2}{*}{ Palak (Beta vulgaris) } & $5 \%$ & $0.37 \mathrm{~g}$ roots plant $^{-1}$ & 0.36 & 5 & Singh et al. (2008) \\
\hline & $20 \%$ & 0.37 & 0.15 & & \\
\hline Wheat straw & $0,0.25$, and $0.5 \%$ & $5.8 \mathrm{t} \mathrm{ha}^{-1}$ & 12.4 & 5 & Tsadilas et al. (2009a) \\
\hline Wheat grain & & $2.1 \mathrm{tha}^{-1}$ & 4.4 & 0.25 & \\
\hline \multirow[t]{2}{*}{ Pigeon pea } & $0,25-100 \%$ & 35.4 pod plant ${ }^{-1}$ & 37.5 & 25 & Pandey et al. (2009) \\
\hline & & 105.7 seed plant ${ }^{-1}$ & 110.2 & & \\
\hline Wheat grain & $100 \mathrm{t} \mathrm{ha}^{-1}$ & $3.0 \mathrm{t} \mathrm{ha}^{-1}$ & 4.4 & 100 & Tripathi et al. (2009) \\
\hline Maize grain & & 2.9 & 4.3 & & \\
\hline Eggplant fruit & & 1.2 & 1.5 & & \\
\hline Mung bean & $0,5-20 \%$ & $94.6 \mathrm{t} \mathrm{ha}^{-1}$ & 105.8 & 10 & Singh and Agrawal (2010) \\
\hline Rice root & 2 and $4 \%$ & $0.15 \mathrm{~g} \mathrm{pot}^{-1}$ & 0.25 & 2 & Gu et al. (2011) \\
\hline Rice steam & & 0.60 & 1.25 & & \\
\hline Rice leaves & & 1.10 & 1.30 & & \\
\hline Maize grain & $200 \mathrm{t} \mathrm{ha}^{-1}$ & $2.5 \mathrm{t} \mathrm{ha}^{-1}$ & 3.2 & 200 & Patra et al. (2012b) \\
\hline Rice grain & & $2.2 \mathrm{tha}^{-1}$ & 3.0 & & \\
\hline Mentha piperita & $0,25-100 \%$ & $6.7 \mathrm{~g} \mathrm{pot}^{-1}$ & 10.5 & 50 & Kumar and Patra (2012) \\
\hline
\end{tabular}

a A range of application rate is given where numerous CFA rates were used.

b All CFA treatments expressed at \% CFA are based on weight (CFA) by weight (soil) basis i.e. w/w.

c Weight of 1000 seeds.

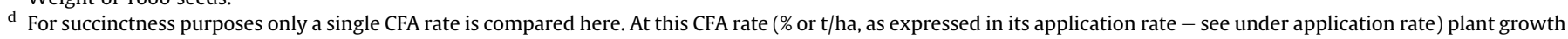
either had a positive/negative no response.

in soil pH (Kim et al., 1994; Tsadilas et al., 2002, 2009b). Patra et al. (2012b) indicated that CFA is a useful soil amendment which can improve the physical and chemical properties of nutrient deficient soils and thus improves the soil fertility and productivity. The risk of soil contamination with CFA-borne PTEs can be mitigated by controlled land application of CFA in terms of its amount and the concentration of PTEs.

\subsection{Microbial properties}

Despite the considerable amount of work on the influence CFA has on soil physical and chemical properties, there is not much information relating to the effects of CFA on soil microbial properties. Coal fly ash can affect soil microbial activity through its influence on $\mathrm{pH}$, salinization, toxicity of boron and other TEs, and by its influence on soil physical conditions (Carlson and Adriano, 1993). A laboratory incubation study showed that the application of CFA to a sandy soil inhibited microbial respiration, enzyme activity and N mineralization (Pandey and Singh, 2010). Wong and Wong (1986) found that CFA addition decreased microbial respiratory activities, especially in a sandy soil, as $\mathrm{CO}_{2}$ evolution decreased considerably in the highest rate of CFA applied. Also, CFA addition may inhibit microbial activity through TEs excess supply to soils, particularly when CFA is applied in excessive amounts and soil reaction $(\mathrm{pH})$ becomes favourable for their solubility, i.e. when acidic CFA is applied to poorly buffered soils. It is well known that rhizobacteria have different tolerance profile to different metals (Pandey and Singh, 2010); thus their activities may be influenced by a particular metal or group of metals when they exceed their tolerance limits. Coal fly ash application to soils (which in general contains TEs - see Table 1), thus can contaminate soils with a variety of TEs which may hinder microbial activity (Adriano et al., 1978). This clearly would depend upon the amount of CFA-borne TEs supplied and their solubility in the soil, which can be controlled by controlling the rate of CFA application and maintaining appropriate soil $\mathrm{pH}$ conditions.

\section{Impact of CFA application on plant growth}

Coal fly ash through its influence on soil physical, chemical and biological properties and processes is likely to affect plants growth and development (Singh et al., 2010; Ukwattage et al., 2013). Research has demonstrated positive benefits of CFA land application for improving soil properties and crop productivity (Skousen et al., 2013).

Many workers (e.g., Ciravolo and Adriano, 1979; Elfving et al., 1981; Aitken et al., 1984; Khan and Khan, 1996; Singh et al., 1997; Matsi and Keramidas, 1999; Dwivedi et al., 2007; Tripathi et al., 2009) have reported that CFA addition generally increases plant growth (Table 2). However, the beneficial effects of CFA on plant growth and productivity are generally best realized when weathered CFA is used because of the above discussed issues related to $\mathrm{pH}$, salinity and phytotoxicity (Ukwattage et al., 2013). Furthermore, in situations where soils have inherent structural and nutritional limitations, the use of CFA can improve crop yields and enhance food security (Ukwattage et al., 2013). Many Studies (e.g., Hill and Lamp, 1980; Elseewi et al., 1980b; Weinstein et al., 1989; Sajwan et al., 1995) have demonstrated that CFA soil application increased crop yield of alfalfa (Medicago sativa), barley (Hordeum vulgare), Bermuda grass (Cynodon dactylon) and white clover (Trifolium repens). Oil seed crops such as sunflower (Helianthus sp.) and groundnut (Arachis hypogaea) also responded positively to CFA 
soil application (Jala and Goyal, 2006). Likewise, greater yield of aromatic grasses, particularly palmarosa (Cymbopogon martini) and citronella (Cymbopogon nardus), in CFA amended soil was attributed to increased availability of major plant nutrients (Asokan et al., 1995). Gratima et al. (2005) found a gradual increase in the yield of succeeding crops after CFA application, and suggested that the effect was probably due to the residual plant-availability of CFAborne nutrients in the soil.

The influence of CFA on plant growth, however, depends on the application rate as summarized in Table 2. In a silt loam treated consecutively with CFA at a rate of $90 \mathrm{t} \mathrm{ha}^{-1}$ for 3 years, soybean yield increased by about 10\% (Kim et al., 1994). Addition of CFA up to $8 \%(w / w)$ to either calcareous or acidic soils resulted in higher yield of several agronomic crops (Page et al., 1979), mainly due to increased plant nutrients availability. Coal fly ash applied on acidic mine spoil strips at various field locations increased the yield of many crops which was attributed to increased soil availability of $\mathrm{Ca}$ and $\mathrm{Mg}$ and prevention of $\mathrm{Al}, \mathrm{Mn}$ and other metallic ions toxicity by neutralizing the soil acidity (Fail and Wochok, 1977). Clearly the use of CFA for reclamation of metalliferous abandoned mining sites or sites affected by acid mine drainage can help neutralize the acidity and mitigate associated problem of metal toxicity and at the same time can supply key soil nutrients for land cover establishment.

Sikka and Kansal (1995) found that CFA soil application (2-4\%, $\mathrm{w} / \mathrm{w}$ ) had a beneficial effect on the dry-matter yield of rice, but a higher level $(8 \%, \mathrm{w} / \mathrm{w})$ had a significant negative effect (Table 2$)$. Kim et al. (1997) also reported similar increases in Chinese cabbage yield, and the concentration of PTEs in the tissues was not increased following the CFA application. Likewise, plant growth was stimulated considerably at the $10 \%(\mathrm{w} / \mathrm{w})$ CFA application rate, as evidenced by $27 \%$ enhanced biomass, with an increase in leaf area and plant height when compared to the untreated control (Singh et al., 1997, Table 2). However, at a higher CFA application rate $(30 \%, \mathrm{w} /$ w), plant growth was retarded, showing a decline of $27 \%$ in dry matter production, though without any manifestation of metal toxicity or mineral deficiency symptoms (Singh et al., 1997, Table 2). Matsi and Keramidas (1999) studied the influence of CFA application on ryegrass growth in two acidic soils. They found that total biomass yield increased considerably following CFA application in both soils. The highest yield was obtained when CFA was applied at $50 \mathrm{~g} \mathrm{~kg}^{-1}$ soil (5\%, w/w; Table 2). In a 120-day greenhouse experiment, Singh and Siddiqui (2003) investigated the effects of various CFA soil application rates on the growth and yield of three cultivars of rice, Oryza sativa. They found that the application rates of $20 \%$ and 40\% CFA resulted in major increases in plant growth and yield of all three rice cultivars (Table 2). Similar effects of CFA in rice production were obtained in other studies (e.g. Lee et al., 2006; Dwivedi et al., 2007, Table 2).

Sinha and Gupta (2005) studied the effects of various levels of CFA $(10,25,50,75$ and $100 \%, w / w)$ on plant growth in a CFA amended soil, seeded with Sesbania cannabina. After 90 days, they found that shoot length and biomass increased up to the 25\% CFA application rate as compared to the untreated control soil (Table 2). On the other hand, Singh et al. (2008) studied the effects of various levels of CFA ( $0 \%, 5 \%, 10 \%, 15 \%$ and $20 \%$ ) application on growth and yield of Beta vulgaris L. The results showed that the higher application doses of CFA (15 and 20\%) caused significant reductions in the growth and biomass yield (Table 2). Tsadilas et al. (2009a) conducted a field experiment with an Alfisol amended with two CFA application rates (5.5 $\mathrm{t} \mathrm{ha}^{-1}$ and $11 \mathrm{t} \mathrm{ha}^{-1}$ ), where wheat (Triticum vulgare) was grown in the CFA treated soil. They reported that CFA application increased the biomass and grain yield of wheat and the yield increased with the application rate (Table 2). Similarly, in a pot experiment where Cajanus cajan was grown in a garden soil amended with CFA $(0,25,50$ and $100 \%, w / w)$, the addition of CFA at $25 \%$ application rate was found to have positive results in most of the studied growth and yield parameters (Pandey et al., 2009, Table 2). The results further confirmed that the lower CFA application rate (25\%) was safe for C. cajan cultivation. However, the yield parameters were adversely affected at higher rates ( 50 and $100 \%, w / w$ ) of CFA compared to the control (Pandey et al., 2009, Table 2).

A field experiment was conducted by Tripathi et al. (2009) to assess the effect of CFA application on the yield and nutrient composition of wheat, maize and eggplant crops grown in sequence on a previously uncultivated land. The ash was mixed with soil at $100 \mathrm{t} \mathrm{ha}^{-1}$. In the case of first crop (wheat), the increase in yield of grain and straw was $29.4 \%$ and $26.6 \%$, respectively, over the untreated control (Table 2). The residual effect of CFA was also observed with increase in the yield of maize grain $(33.1 \%$ - 2nd crops) and eggplant (18.4\% - 3rd crops). This clearly demonstrates that when applied in appropriate amounts CFA as a soil amendment can help increase and sustain crop productivity. Likewise, field experiments were conducted by Singh and Agrawal (2010) to evaluate the effect of CFA on growth and yield of three locally grown cultivars of an important leguminous plant mung bean (Vignaradiata L.) on a soil amended with different levels of CFA (0, 5, $10,15$, and $20 \%, w / w)$. A significant positive response in all the growth parameters was recorded at $10 \%$ CFA treatment for all the cultivars tested (Table 2).

An interesting alternative from a safety point of view is to use CFA for ornamental plants and oil seed crops, which are grown for their aesthetic purposes and thus the accumulation of TEs in plant biomass is not of much concern. Experiments to evaluate the effect of CFA application (0\%, 25\%, 50\%, 75\% and 100\%) on growth and yield of Mentha piperita plant (essential oil bearing crop) showed that application of CFA at $>50 \%$ reduced plant growth and oil yield, whereas addition of CFA at level of $\leq 50 \%$ exhibited positive results (Kumar and Patra, 2012, Table 2).

The findings from abovementioned studies conclude that application of agronomic doses of CFA improves soil properties and fertility as well as enhances growth and yield of crops. However, CFA when applied in larger amounts than site-specific requirements adverse effects are inevitable. In such situations, retardation of plant growth could result from metal toxicity and low availability of nitrogen (usually not present in CFAs in any significant amounts) and phosphorus (CFAs contain considerable amounts of $\mathrm{P}$ but is not in a forms readily available to plants). Furthermore, given the variability in the nature and composition of CFA ( $\mathrm{pH}$, major- and micro-nutrients) and that of soil ( $\mathrm{pH}$, texture, fertility), a specific CFA application rate cannot be recommended. For example, an already fertile soil may not show any positive effect, and if the CFA application significantly raises its $\mathrm{pH}$ it may even have negative effects on plant growth due to reduced supply of soil nutrients. Clearly all these factors should be taken into consideration in order to work out appropriate rates of CFA application for soil site-specific improvements.

\section{Impact of CFA on plant-availability and uptake of nutrients and TEs}

Coal fly ash can be a valuable source of readily available plant micro- and macro-nutrients (Table 1). Fly ash has been used as a source of essential plant nutrients in agriculture and forestry (Ram et al., 2006a, 2007). The resultant increase in soil nutrients by CFA application is expected to enhance crop productivity (Sims et al., 1995), as noted in Section 4. Coal fly ash inputs in general greatly increase soil content of $\mathrm{P}, \mathrm{K}, \mathrm{B}, \mathrm{Ca}, \mathrm{Mg}, \mathrm{Mn}, \mathrm{Zn}$, carbonate, bicarbonate, and sulphate (Khan and Singh, 2001). The use of CFA in agriculture has been based on its liming potential and supply of 
nutrients such as $\mathrm{Ca}, \mathrm{Na}, \mathrm{K}, \mathrm{P}, \mathrm{Mg}, \mathrm{B}, \mathrm{S}$ and Mo, which promote plant growth and also alleviate the condition of nutrient deficiency in soils (Kumpiene et al., 2007; Sajwan et al., 2003). Many greenhouse and field studies indicate that many chemical constituents of CFA can improve the agronomic and fertility properties of the soil (Adriano et al., 1980; Elseewi et al., 1981; Sikka and Kansal, 1995; Singh et al., 1997).

\subsection{Impact of CFA on plant-availability and uptake of macro elements}

Table 3 summarizes the influence of CFA application on the content of nutrients and TEs in plants grown on CFA amended soils. Sikka and Kansal (1995) reported that rice grown on 7 soils amended with CFA $(0,2,4$ and $8 \%, w / w)$ had increased uptake of macro nutrients (N, S, and Ca; Table 3). Tripathi et al. (2009) evaluated the effect of CFA application (100 t ha ${ }^{-1}$ ) on macro nutrient uptake by wheat, maize and eggplant crops grown in sequence. They found that the CFA application increased the plant uptake of macronutrients ( $\mathrm{N}, \mathrm{P}, \mathrm{K}, \mathrm{S}, \mathrm{Ca}$ and $\mathrm{Mg}$ ), which is not surprising as they found the ash, in addition to significant amounts of these nutrients, also contained $30 \mathrm{mg} \mathrm{N} \mathrm{kg}^{-1}$ (Table 3). Tsadilas et al. (2009a) found that application of CFA to an acidic Alfisol under field conditions increased wheat plant concentrations of N, P, K and Ca (Table 3).

Coal fly ash does not seem to be an optimal source of P, particularly when compared with its readily soluble source - mono calcium phosphate, biomass ash (rice husk ash), and bagasse ash (Martens et al., 1970; Martens, 1971; Schiemenz and EichlerLobermann, 2010; Thind et al., 2012). Similar findings of no significant change in plant available $\mathrm{P}$ were obtained following CFA application to acidic soils (Sikka and Kansal, 1995; Matsi and Keramidas, 1999; Tsadilas et al., 2009a, Table 3). In some cases plant P uptake was reduced (Tsadilas et al., 2009b, Table 3), manifesting in $\mathrm{P}$ deficiency symptoms because of the decrease in $\mathrm{P}$ availability to plants in ash treated soils. This is possibly due to CFAinduced increase in soil $\mathrm{pH}$ (Adriano et al., 1978), and perhaps also due to the interaction of CFA-borne Fe, $\mathrm{Al}$ and $\mathrm{Ca}$ with soluble soil-P source, resulting in reduced soluble P supply.

The aforementioned studies show that CFA can be beneficial for crop production by improving the fertility and physical, chemical and biological properties of the soil. There are examples of more than $100 \%$ increases in crop yields with CFA application. On the other hand, studies show more than $50 \%$ reduction in plant growth following CFA application, the adverse effects arising from phytotoxicity caused by trace elements and salinity of the ash (Table 3). From various reviews and many individual studies reviewed here (see Tables 2 and 3), it appears that rather than using the ash as a general soil amendment it should be strategically selected to target specific soil problems. This should be in situations in which CFA provides a low-cost alternative to other products, and also poses minimal risk to yield and its quality or to the environment.

\subsection{Impact of CFA on plant-availability and uptake of micro elements}

Plant uptake of micronutrients and PTEs is often reflective of their amounts added through CFA additions unless the amendment induces major changes in soil pH. In a field study (1993-1996), Adriano et al. (2002) assessed the effects of applying unusually high rates $\left(0,280,560\right.$, and $\left.1120 \mathrm{tha}^{-1}\right)$ of CFA as a soil amendment for turfgrass, seeded with centipedegrass (Eremochloa ophiroides). The results showed that CFA soil application increased the plant tissue concentrations of B, Mn, Se, and Zn (Table 3).
Boron is a unique trace element. Although B is essential for plant growth, the difference between its sufficiency and toxicity is the smallest among the micronutrients (Mengel and Kirkby, 1987; Bergmann, 1993). One concern for plants grown in CFA amended soil is B toxicity due to significant levels of B in CFA (Ukwattage et al., 2013). Application of fresh CFA can produce B toxicity in some plants, but B toxicity was not observed in plants grown on soils amended with weathered CFA because most of plant-available B readily leaches from soil (Clark et al., 2001).

Sinha and Gupta (2005) while comparing various levels of CFA application $(10,25,50,75$ and $100 \%, w / w)$ found that metal uptake by Sesbania cannabina plants was in the order of $\mathrm{Fe}>\mathrm{Mn}>\mathrm{Zn}>\mathrm{Cu}>\mathrm{Pb}>\mathrm{Ni}$, reflective of their additions and their chemical behaviour in soils. The work of Tripathi et al. (2009) further showed that CFA application enhanced the soil pool of plant-available micronutrients ( $\mathrm{Fe}, \mathrm{Mn}, \mathrm{Zn}$, and $\mathrm{Ni}$ ) while that of some PTEs (e.g. Cu, Pb, Cr, Se, and Mo) was only slightly increased, particularly for the second and third crops after the CFA application (Table 3). The plant uptake of PTEs ( $\mathrm{Pb}, \mathrm{Se}, \mathrm{Cr}$, and $\mathrm{Cu}$ ) while elevated compared to the non-amended soil, they remained below their threshold levels (Tripathi et al., 2009, Table 3). Overall, the plant-available pool of micro-nutrients in the soils remained greater than their respective untreated control, even after harvesting three crops, illustrating the usefulness of CFA for micronutrient supply and soil fertility maintenance (Tripathi et al., 2009). Similarly, Tsadilas et al. (2009a) found that application of CFA to an acidic Alfisol field soil increased wheat plant tissue concentrations of $\mathrm{B}, \mathrm{Cu}$, and $\mathrm{Zn}$, while those of Fe and $\mathrm{Mn}$ decreased (Table 3).

In another study, Singh et al. (2008) investigated the effects of various CFA application rates $(0 \%, 5 \%, 10 \%, 15 \%$ and $20 \%, w / w)$ on PTEs accumulation by spinach (Beta vulgaris L.), a plant species known for accumulating large amount of metals. The results showed that the concentrations of $\mathrm{Cu}, \mathrm{Zn}, \mathrm{Cd}, \mathrm{Pb}, \mathrm{Ni}$ and $\mathrm{Cr}$ increased significantly with the CFA application rate (Table 3). The study concludes that B. vulgaris can accumulate excess amounts of metals following CFA application, which is hardly surprising as spinach and other leafy vegetables are known to accumulate significant amount of metals as compared to seed or root crops (Hooda et al., 1997; Hooda, 2010). It is thus advisable that leafy vegetable like $B$. vulgaris is not a suitable crop to be grown where CFA is used as soil amendment. Gupta and Sinha (2009) reported that accumulation of PTEs such as Ni and Pb in Vigna radiate seeds was many times higher in CFA amended soils compared to the non-amended soil (Table 3). Overall it seems the use of CFA can be a useful source of essential micronutrients. Like other wastes (e.g. sewage sludge), its land application in excessive amounts or uncontrolled disposal is likely to present a significant risk of PTEs entry into the food chain.

\section{Coal fly ash application for reclamation of acidic and degraded soils}

Worldwide, nearly $2 \times 10^{9}$ ha of land is considered to be degraded to some degree (Oldeman and Vanengelen, 1993) and reclamation of such a vast land mass is necessary to meet the increasing food production demand (Lin and Ho, 2003) and for ecosystem restoration and functionality. In this regard, considerable research efforts have led to the development of practices which rely on the use of amendments such as lime, gypsum and organic materials for degraded land reclamation purposes. However, large-scale use of such amendments has been restricted due to economic considerations and limited availability of the materials needed. Industrial by-products, like coal and biofuel combustion wastes, such as alkaline CFA can be used as a useful soil ameliorant (Sajwan et al., 2003; Ukwattage et al., 2013; Skousen et al., 2013). 
Table 3

Effect of CFA application on nutrients and TEs content in the grown plants.

\begin{tabular}{|c|c|c|c|c|c|c|}
\hline \multirow[t]{2}{*}{ Element } & \multirow[t]{2}{*}{ Plant } & \multirow[t]{2}{*}{ Plant tissue } & \multicolumn{2}{|c|}{ Concentrations } & \multirow{2}{*}{$\begin{array}{l}\text { FA application } \\
\text { rate, } \mathrm{t} \mathrm{ha}^{-1}\end{array}$} & \multirow[t]{2}{*}{ References } \\
\hline & & & Control & FA-treated soil & & \\
\hline \multicolumn{7}{|c|}{ Trace elements, $\mathrm{mg} \mathrm{kg}^{-1}$} \\
\hline \multirow[t]{8}{*}{ Boron } & Turf grass & Whole plant & 10.8 & 22.3 & 280 & Adriano et al. (2002) \\
\hline & & & & 13.7 & 560 & \\
\hline & & & & 13.8 & 1120 & \\
\hline & Ryegrass & Above ground biomass & $10-60$ & $16-90$ & 100 & Matsi and Keramidas (1999) \\
\hline & Wheat & Above ground biomass & 9.5 & 11.0 & 5.5 & Tsadilas et al. (2009a) \\
\hline & & & 9.5 & 11.5 & 11 & \\
\hline & & & 20.7 & 22.5 & 5.5 & Tsadilas et al. (2009b) \\
\hline & & & 20.7 & 19.0 & 11 & \\
\hline \multirow[t]{5}{*}{ Cadmium } & Chicory & Aboveground biomass & 2.6 & 1.8 & 60 & Scotti et al. (1999) \\
\hline & Rice & Grain & 0.13 & 0.12 & 200 & Rautaray et al. (2003) \\
\hline & Rice & Straw & 0.17 & 0.16 & & \\
\hline & Mustard & Seed & 0.16 & 0.17 & & \\
\hline & Mustard & Stover & 0.17 & 0.18 & & \\
\hline \multirow[t]{13}{*}{ Copper } & Rice & Above ground biomass & 7.9 & 8.2 & 80 & Sikka and Kansal (1995) \\
\hline & Wheat & & 7.6 & 7.8 & & \\
\hline & Wheat & Grain & 2.2 & 2.6 & 100 & Tripathi et al. (2009) \\
\hline & Maize & Grain & 2.1 & 2.2 & & \\
\hline & Eggplant & Fruit & 4.0 & 4.6 & & \\
\hline & Chicory & Above ground biomass & 8.3 & 6.8 & 60 & Scotti et al. (1999) \\
\hline & Mustard & Root & 4.6 & 3.7 & 1000 & Gupta and Sinha (2006) \\
\hline & & Shoot & 5.0 & 4.5 & & \\
\hline & & Seed & 6.3 & 2.6 & & \\
\hline & Wheat & Above ground biomass & 7.3 & 8.4 & 5.5 & Tsadilas et al. (2009a) \\
\hline & & & 7.3 & 8.4 & 11 & \\
\hline & & & 32.5 & 33.7 & 5.5 & Tsadilas et al. (2009b) \\
\hline & & & 32.5 & 31.2 & 11 & \\
\hline \multirow[t]{16}{*}{ Zinc } & Rice & Above ground biomass & 26.3 & 23.3 & 80 & Sikka and Kansal (1995) \\
\hline & Wheat & & 23.4 & 23.0 & & \\
\hline & Wheat & Grain & 1.5 & 1.7 & 100 & Tripathi et al. (2009) \\
\hline & Maize & Grain & 12.3 & 13.0 & & \\
\hline & Eggplant & Fruit & 11.7 & 12.3 & & \\
\hline & Chicory & Above ground biomass & 30.1 & 10.5 & 60 & Scotti et al. (1999) \\
\hline & Mustard & Root & 12.2 & 38.5 & 1000 & Gupta and Sinha (2006) \\
\hline & & Shoot & 11.8 & 8.1 & & \\
\hline & & Seed & 18.5 & 13.4 & & \\
\hline & Turfgrass & Whole plant & 59.2 & 44.0 & 280 & Adriano et al. (2002) \\
\hline & & & 59.2 & 41.0 & 560 & \\
\hline & & & 59.2 & 43.8 & 1120 & \\
\hline & Wheat & Above ground biomass & 90 & 61 & 5.5 & Tsadilas et al. (2009a) \\
\hline & & & 90 & 113 & 11 & \\
\hline & & & 58.5 & 53.0 & 5.5 & Tsadilas et al. (2009b) \\
\hline & & & 58.5 & 33.0 & 11 & \\
\hline Manganese & Rice & Above ground biomass & 25.6 & 26.1 & 80 & Sikka and Kansal (1995) \\
\hline & Wheat & & 21.8 & 19.6 & & \\
\hline & Wheat & Grain & 13.8 & 14.3 & 100 & Tripathi et al. (2009) \\
\hline & Maize & Grain & 11.5 & 12.2 & & \\
\hline & Eggplant & Fruit & 15.8 & 16.5 & & \\
\hline & Mustard & Root & 3.7 & 3.6 & 1000 & Gupta and Sinha (2006) \\
\hline & & Shoot & 13.2 & 9.4 & & \\
\hline & & Seed & 15.5 & 10.5 & & \\
\hline & Turfgrass & Whole plant & 264 & 104 & 280 & Adriano et al. (2002) \\
\hline & & & 264 & 100 & 560 & \\
\hline & & & 264 & 100 & 1120 & \\
\hline & Wheat & Above ground biomass & 68.7 & 60.0 & 5.5 & Tsadilas et al. (2009a) \\
\hline & & & 68.7 & 48.5 & 11 & \\
\hline & & & 152 & 31 & 5.5 & Tsadilas et al. (2009b) \\
\hline & & & 152 & 26 & 11 & \\
\hline Iron & Rice & Above ground biomass & 176 & 197 & 80 & Sikka and Kansal (1995) \\
\hline & Wheat & & 138 & 127 & & \\
\hline & Wheat & Grain & 34 & 38 & 100 & Tripathi et al. (2009) \\
\hline & Maize & Grain & 28 & 29 & & \\
\hline & Eggplant & Fruit & 11 & 12 & & \\
\hline & Mustard & Root & 95 & 123 & 1000 & Gupta and Sinha (2006) \\
\hline & & Shoot & 171 & 179 & & \\
\hline & & Seed & 186 & 95 & & \\
\hline & Wheat & Above ground biomass & 75 & 74 & 5.5 & Tsadilas et al. (2009a) \\
\hline & & & 75 & 71 & 11 & \\
\hline
\end{tabular}


Table 3 (continued)

\begin{tabular}{|c|c|c|c|c|c|c|}
\hline \multirow[t]{2}{*}{ Element } & \multirow[t]{2}{*}{ Plant } & \multirow[t]{2}{*}{ Plant tissue } & \multicolumn{2}{|c|}{ Concentrations } & \multirow{2}{*}{$\begin{array}{l}\text { FA application } \\
\text { rate, } \mathrm{t} \mathrm{ha}^{-1}\end{array}$} & \multirow[t]{2}{*}{ References } \\
\hline & & & Control & FA-treated soil & & \\
\hline & & & 120 & 84 & 5.5 & Tsadilas et al. (2009b) \\
\hline & & & 120 & 118 & 11 & \\
\hline \multirow[t]{11}{*}{ Nickel } & Wheat & Grain & 0.67 & 0.73 & 100 & Tripathi et al. (2009) \\
\hline & Maize & Grain & 0.50 & 0.65 & & \\
\hline & Eggplant & Fruit & 0.26 & 0.31 & & \\
\hline & Chicory & Above ground biomass & 7.2 & 6.0 & 60 & Scotti et al. (1999) \\
\hline & Mustard & Root & 10.4 & 79.4 & 1000 & Gupta and Sinha (2006) \\
\hline & & Shoot & 17.8 & 191.0 & & \\
\hline & & Seed & 8.6 & 106.8 & & \\
\hline & Rice & Grain & 2.2 & 2.1 & 200 & Rautaray et al. (2003) \\
\hline & Rice & Straw & 1.4 & 0.8 & & \\
\hline & Mustard & Seed & 1.9 & 1.1 & & \\
\hline & Mustard & Stover & 0.7 & 0.6 & & \\
\hline \multirow[t]{8}{*}{ Lead } & Wheat & Grain & 0.38 & 0.41 & 100 & Tripathi et al. (2009) \\
\hline & Maize & Grain & 0.40 & 0.55 & & \\
\hline & Eggplant & Fruit & 0.32 & 0.41 & & \\
\hline & Mustard & Root & 1.0 & 1.5 & 1000 & Gupta and Sinha (2006) \\
\hline & & Shoot & 0.9 & 1.9 & & \\
\hline & & Seed & 2.9 & 2.2 & & \\
\hline & Wheat & Above ground biomass & 12.5 & 21.0 & 5.5 & Tsadilas et al. (2009b) \\
\hline & & & 12.5 & 22.7 & 11 & \\
\hline \multirow[t]{6}{*}{ Molybdenum } & Wheat & Grain & 0.36 & 0.39 & 100 & Tripathi et al. (2009) \\
\hline & Maize & Grain & 0.45 & 0.50 & & \\
\hline & Eggplant & Fruit & 0.36 & 0.41 & & \\
\hline & Turf grass & Whole plant & 4.5 & 18.0 & 280 & Adriano et al. (2002) \\
\hline & & & 4.5 & 28.7 & 560 & \\
\hline & & & 4.5 & 35.6 & 1120 & \\
\hline \multirow[t]{6}{*}{ Selenium } & Wheat & Grain & 0.19 & 0.21 & 100 & Tripathi et al. (2009) \\
\hline & Maize & Grain & 0.20 & 0.25 & & \\
\hline & Eggplant & Fruit & 0.17 & 0.20 & & \\
\hline & Turf grass & Whole plant & 0.13 & 1.2 & 280 & Adriano et al. (2002) \\
\hline & & & 0.13 & 2.3 & 560 & \\
\hline & & & 0.13 & 4.0 & 1120 & \\
\hline \multirow[t]{3}{*}{ Chromium } & Wheat & Grain & 0.59 & 0.61 & 100 & Tripathi et al. (2009) \\
\hline & Maize & Grain & 0.30 & 0.38 & & \\
\hline & Eggplant & Fruit & 0.23 & 0.30 & & \\
\hline Macronutrient & & & & & & \\
\hline Nitrogen & Rice & Above ground biomass & 1.5 & 1.7 & 80 & Sikka and Kansal (1995) \\
\hline & Wheat & & 2.8 & 2.8 & & \\
\hline & Wheat & Grain & 1.9 & 2.0 & 100 & Tripathi et al. (2009) \\
\hline & Maize & Grain & 1.5 & 1.6 & & \\
\hline & Eggplant & Fruit & 2.0 & 2.1 & & \\
\hline & Wheat & Above ground biomass & 1.0 & 1.2 & 5.5 & Tsadilas et al. (2009a) \\
\hline & & & 1.0 & 1.2 & 11 & \\
\hline & & & 2.1 & 3.0 & 5.5 & Tsadilas et al. (2009b) \\
\hline & & & 2.1 & 3.2 & 11 & \\
\hline Phosphorus & Rice & Above ground biomass & 0.21 & 0.19 & 80 & Sikka and Kansal (1995) \\
\hline & Wheat & & 0.27 & 0.27 & & \\
\hline & Wheat & Grain & 0.23 & 0.27 & 100 & Tripathi et al. (2009) \\
\hline & Maize & Grain & 0.16 & 0.19 & & \\
\hline & Eggplant & Fruit & 0.14 & 0.17 & & \\
\hline & Wheat & Above ground biomass & 0.42 & 0.44 & 5.5 & Tsadilas et al. (2009a) \\
\hline & & & 0.42 & 0.47 & 11 & \\
\hline & & & 0.40 & 0.30 & 5.5 & Tsadilas et al. (2009b) \\
\hline & & & 0.40 & 0.37 & 11 & \\
\hline Potassium & Rice & Above ground biomass & 2.5 & 2.6 & 80 & Sikka and Kansal (1995) \\
\hline & Wheat & & 5.1 & 5.1 & & \\
\hline & Wheat & Grain & 1.6 & 1.6 & 100 & Tripathi et al. (2009) \\
\hline & Maize & Grain & 1.5 & 1.6 & & \\
\hline & Eggplant & Fruit & 2.0 & 2.1 & & \\
\hline & Wheat & Above ground biomass & 0.9 & 1.1 & 5.5 & Tsadilas et al. (2009a) \\
\hline & & & 0.9 & 1.1 & 11 & \\
\hline & & & 0.34 & 0.43 & 5.5 & Tsadilas et al. (2009b) \\
\hline & & & 0.34 & 0.44 & 11 & \\
\hline Calcium & Rice & Above ground biomass & 0.23 & 0.25 & 80 & Sikka and Kansal (1995) \\
\hline & Wheat & & 0.01 & 0.01 & & \\
\hline & Wheat & Grain & 0.15 & 0.18 & 100 & Tripathi et al. (2009) \\
\hline & Maize & Grain & 0.14 & 0.17 & & \\
\hline
\end{tabular}


Table 3 (continued)

\begin{tabular}{|c|c|c|c|c|c|c|}
\hline \multirow[t]{2}{*}{ Element } & \multirow[t]{2}{*}{ Plant } & \multirow[t]{2}{*}{ Plant tissue } & \multicolumn{2}{|c|}{ Concentrations } & \multirow{2}{*}{$\begin{array}{l}\text { FA application } \\
\text { rate, } \mathrm{t} \mathrm{ha}^{-1}\end{array}$} & \multirow[t]{2}{*}{ References } \\
\hline & & & Control & FA-treated soil & & \\
\hline & Eggplant & Fruit & 0.39 & 0.43 & & \\
\hline & Wheat & Above ground biomass & 0.18 & 0.23 & 5.5 & Tsadilas et al. (2009a) \\
\hline & & & 0.18 & 0.22 & 11 & \\
\hline & & & 0.53 & 0.74 & 5.5 & Tsadilas et al. (2009b) \\
\hline & & & 0.53 & 0.93 & 11 & \\
\hline \multirow[t]{9}{*}{ Magnesium } & Rice & Above ground biomass & 0.18 & 0.19 & 80 & Sikka and Kansal (1995) \\
\hline & Wheat & & 0.20 & 0.21 & & \\
\hline & Wheat & Grain & 0.10 & 0.13 & 100 & Tripathi et al. (2009) \\
\hline & Maize & Grain & 0.08 & 0.11 & & \\
\hline & Eggplant & Fruit & 0.19 & 0.23 & & \\
\hline & Wheat & Above ground biomass & 0.08 & 0.08 & 5.5 & Tsadilas et al. (2009a) \\
\hline & & & 0.08 & 0.07 & 11 & \\
\hline & & & 0.16 & 0.30 & 5.5 & Tsadilas et al. (2009b) \\
\hline & & & 0.16 & 0.31 & 11 & \\
\hline \multirow[t]{5}{*}{ Sulphur } & Rice & Above ground biomass & 0.18 & 0.19 & 80 & Sikka and Kansal (1995) \\
\hline & Wheat & & 0.11 & 0.11 & & \\
\hline & Wheat & Grain & 0.21 & 0.25 & 100 & Tripathi et al. (2009) \\
\hline & Maize & Grain & 0.08 & 0.11 & & \\
\hline & Eggplant & Fruit & 0.12 & 0.19 & & \\
\hline
\end{tabular}

Coal fly ash is one of the cheapest and widely available waste materials suitable for reclamation of degraded soils (Pandey et al., 2012). Results from many studies suggest enormous potential for the use of CFA to improve cultivable, degraded/waste land and mining-affected soils for agriculture and forestry (Ram and Masto, 2014). The concept of CFA application in agriculture and forestry is not new. Because of its useful physico-chemical properties including the considerable content of macro-nutrients ( $\mathrm{P}, \mathrm{K}, \mathrm{Ca}, \mathrm{Mg}$, and $\mathrm{S}$ ) and micro-nutrients ( $\mathrm{Cu}, \mathrm{Zn}, \mathrm{Mn}$, and $\mathrm{Fe}$ ), the use of CFA has been advocated over the last three decades (Page et al., 1979; Adriano et al., 1980; El-Mogazi et al., 1988; Yunusa et al., 2006; Kumar and Patra, 2012). The presence of almost all essential plant nutrients in CFA (Table 1) and its ameliorating effects on physical and chemical nature of the soil thus makes CFA a useful amendment for crop production especially for degraded soils and waste lands (Ram et al., 2006b; Ukwattage et al., 2013).

The use of CFA on acidic soils can improve their physical, chemical and biological properties (Pandey and Singh, 2010). Coal fly ash depending on its characteristics, including its acidity/alkalinity could be used, as an ameliorating agent for acidic (Ram et al., 2007) and sodic soils (Kumar and Singh, 2003), as an effective and safe fertilizer (Gupta et al., 2004), and to convert the problematic soils including wasteland into agricultural land or for re-vegetation purposes (Bhumbla et al., 1991; Shukla and Mishra, 1986).

One foremost beneficial use of CFA land application could be as an amendment to mitigate problems associated with low soil pH. Many acidic soils have sufficiently low $\mathrm{pH}(<5)$ to be detrimental to plants (Kabata-Pendias, 2011). Some deleterious effects of soil acidity are greater solubility of many TEs which may become phytotoxic and detrimental to animals/humans when sufficient quantities of these elements accumulate in plant tissues consumed by organisms (Hooda, 2010; Kabata-Pendias, 2011). The pH of acidic soils usually needs to be raised to alleviate many detrimental effects that these soils induce on plants and other soil biota. Although limestone $\left[\mathrm{CaCO}_{3}\right.$ and/or $\left.\mathrm{CaMg}\left(\mathrm{CO}_{3}\right)_{2}\right]$ has been commonly used as an amendment to increase soil $\mathrm{pH}$, many CFAs, especially those containing alkalizing agents [e.g. $\mathrm{CaO}, \mathrm{Ca}(\mathrm{OH})_{2}$, and $\mathrm{CaCO}_{3}$ ], have good potential to rectify soil acidity problems. One major problem with calcitic limestone is that the main reactive compound is so insoluble that it is only effective at the site of incorporation in soil because it is not readily leached or diffused in the wider soil (Shaheen and Tsadilas, 2013).

Alkaline CFAs can be used as a substitute for lime and additionally they can supply vital plant nutrients. Tsadilas et al. (2009a) examined the effect of CFA application on soil properties and wheat grown on an acidic ( $\mathrm{pH}, 5.6)$ Alfisol. They concluded that CFA application increased soil pH (from 5.6 to 6.6 and 7.5, respectively for 5.5 and $11 \mathrm{t} \mathrm{ha}^{-1}$ CFA application rates), with significant enhancement in wheat biomass and grain yields compared to the untreated control soil. Therefore, CFA can ameliorate acidic and degraded soils for the following reasons: CFA increases the surface area available for element sorption, improves the physical properties of soil (Gorman et al., 2000), neutralizes the $\mathrm{pH}$ of acidic soils and renders most cationic metals less mobile (Ciccu et al., 2003). Also, CFA contains $\mathrm{K}$ and alkaline earth elements ( $\mathrm{Ca}, \mathrm{Mg}$ ) that are essential plant nutrients. A mixture of CFA with acidic soils rich in organic matter is expected to further enhance biological activity in the soil (Jala and Goyal, 2006), reducing leaching of major nutrients (Sajwan et al., 2003) and be beneficial for vegetation (Rautaray et al., 2003; Tripathi et al., 2009).

Acid mine drainage, mine-tailings ponds, and mineralized waste dumps are sources of toxic metal pollutants and acidity. Coal fly ash as a soil amendment has been suggested to be capable of restoring acid mine drainage affected land and increased metal solubility problems (Misra et al., 1996; Iyer and Scott, 2001; Xenidis et al., 2002). Studies have indicated that land application of CFA improves the physical, chemical and biological qualities of such mining activities affected soils. The use of CFA as a soil amendment for contaminated mine sites would solve several problems by reducing the amounts of other soil ameliorants (fertilizers, lime) required and by decreasing the mobility and bioavailability of PTEs (Ciccu et al., 2003; Mittra et al., 2005). However, in view of the variability in the characteristics of CFAs that are associated with location, feed coal, combustion conditions and other CFA factors, the suitability of a particular CFA for a specific soil/mine spoil needs to be carefully evaluated before it is applied in order to maximize favourable results and to prevent unexpected consequences.

\section{Co-application of CFA with sewage sludge as soil amendment}

A considerable amount of research has assessed blending CFA with a variety of organic and inorganic materials (e.g., gypsum, red mud, animal manure, poultry litter, sewage sludge, compost, press mud, biochar, etc.) for land improvement purposes. Co-application of CFA with these materials has many advantages, such as enhanced 
nutrient availability, decreased PTEs bioavailability, pH buffering, organic matter addition, microbial stimulation and overall improvement in the soil general health. CFA blended with organic and inorganic materials performs better than CFA applied alone (Ram and Masto, 2014).

Sewage sludge (SS) is the most promising amendment for its coapplication with CFA. Both CFA and SS are produced in large quantities; they contain useful nutrients and potentially toxic chemicals. However, their controlled use as soil amendments can turn them in useful resources. Combined use of CFA and SS for land application could prove a beneficial means of their disposal. Because of their contrasting and complementary chemical properties and nutrient contents, land application of both products as mixture thus can improve soil quality and crop production. This could help alleviate waste disposal and management problems associated with land application of SS or CFA separately (Sajwan et al., 2003).

Historically, the use of CFA in agriculture has been based on its liming potential and supply of essential elements such as $\mathrm{Ca}, \mathrm{B}, \mathrm{S}$ and Mo. However, the use of CFA as an agricultural amendment can be enhanced by blending it with potentially acid-forming organic by-products such as SS, poultry and cattle manure which are rich in N and P (Adriano et al., 1980). Moreover, the alkalinity of CFA should promote the neutralization of acidic organic by-products induced soil acidity, resulting from SS decomposition (Hooda and Alloway, 1993), thereby minimizing the bioavailability of PTEs. Sajwan et al. (1995) conducted a greenhouse experiment to evaluate the effect of CFA and SS mixtures in various ratios on the growth and nutrient uptake by Sorghum vulgaris. They reported that the application of 124 or $247 \mathrm{t} \mathrm{ha}^{-1}$ of CFA and SS mixture increased plant biomass by approximately 10 -fold for all CFA + SS mixture ratios compared to the control soil, which received no nutrients or manure application. Overall, the case study showed that a mixture of CFA + SS (1:1) as a soil amendment could provide benefits in terms of soil fertility improvement without any significant risk of soil, water or plants being contaminated, particularly when applied at a reasonable rate of application.

Shaheen and Tsadilas (2013) studied the influence of CFA on sorption and availability of phosphorus to canola grown in a previously SS-amended Alfisol. They reported that treatment of the SSamended soil by CFA increased significantly canola biomass yield and plant available-P compared to the control (previously SSamended soil). The benefits of combined use of CFA and SS were further illustrated in a field study by Tsadilas et al. (2009a). The study examined the influence of CFA and SS application either separately or combined on wheat (Triticum vulgare) biomass production and nutrient availability in an acidic Alfisol. The treatments included fertilization with the conventional inorganic fertilizers $(\mathrm{N}$ and $\mathrm{P}$ ) and application of various doses of CFA applied alone [5.5 $\mathrm{t} \mathrm{ha}^{-1}\left(\mathrm{CFA}_{1}\right)$ and $11 \mathrm{t} \mathrm{ha}^{-1}\left(\mathrm{CFA}_{2}\right)$ ] or mixed with SS [5.5 $\mathrm{t}$ CFA $\mathrm{ha}^{-1}+6 \mathrm{t} \mathrm{SS} \mathrm{ha}^{-1}\left(\mathrm{CFA}_{1}+\mathrm{SS}_{1}\right)$ and 5.5 t CFA ha ${ }^{-1}+12 \mathrm{t} \mathrm{SS} \mathrm{ha}^{-1}$ $\left.\left(\mathrm{CFA}_{1}+\mathrm{SS}_{2}\right)\right]$. Results from this study show that mixing of CFA with SS increased soil $\mathrm{pH}$, organic matter content and soil nutrient supply. Another study where an acidic Alfisol amended with various doses of CFA i.e. $0.25 \%\left(\mathrm{CFA}_{1}\right)$ and $0.5 \%\left(\mathrm{CFA}_{2}\right)$, sewage sludge $0.28 \%\left(\mathrm{SS}_{1}\right)$ and $0.56 \%\left(\mathrm{SS}_{2}\right)$, and coal fly ash + sewage sludge $\left(\mathrm{CFA}_{1}+\mathrm{SS}_{1}\right.$ and $\left.\mathrm{CFA}_{1}+\mathrm{SS}_{2}\right)$ illustrated the benefits of combined CFA + SS application (Tsadilas et al., 2009b). For example, the results showed that CFA application with SS decreased significantly the TEs bioavailability compared to the control and SS alone treatment. The mechanism behind reduced bioavailability of PTEs by combined application of CFA and SS is due to their increased sorption in the soil as found by Tsadilas et al. (2009c). The authors found that simultaneous soil application of CFA and SS increased the partition coefficient $\left(K_{\mathrm{d}}\right)$ of $\mathrm{Zn}$ and $\mathrm{Cu}$ by 4.2 and 3.5 times, respectively as compared to soil amended with SS only. Similar influence of CFA and SS application on Cd and Pb sorption by an acidic Alfisol was also observed (Shaheen and Tsadilas, 2010). These results (Tsadilas et al., 2009c; Shaheen and Tsadilas, 2010) suggest that alkaline CFA is very useful as a low-cost sorbent for SS-borne $\mathrm{Cd}, \mathrm{Cu}, \mathrm{Pb}$ and $\mathrm{Zn}$, and can be used as an ameliorant for SSamended acidic soils. These findings are consistent with those of Su and Wong (2004) who reported similar decreases in the bioavailability of $\mathrm{Zn}, \mathrm{Cu}, \mathrm{Ni}$ and $\mathrm{Cd}$ in soils amended with CFAstabilized sewage sludge. The decrease in metal bioavailability (as assessed by the DTPA extractability test) was supported by plant metal uptake, as with increasing CFA amendment rate, concentrations of $\mathrm{Zn}$ and $\mathrm{Cu}$ in corn shoot tissues decreased (Su and Wong, 2004). These results further demonstrate that CFA stabilized SS not only improves the growth of corn but also reduces the bioavailability of sludge-borne PTEs.

One concern though is that CFA stabilized SS or co-application of CFA and SS may inhibit plant nutrient availability, particularly SSborne phosphorus. Recent work which investigated the influence of CFA-stabilized SS on plant availability of $\mathrm{P}, \mathrm{Cu}$, and $\mathrm{Zn}$ in an incubation experiment involving fluvial and calcareous soils suggests that the plant availability of $P$ was not affected, while the availability of $\mathrm{Cu}$ and $\mathrm{Zn}$ decreased significantly compared to the SS treatment alone (Shaheen et al., 2012a). This, however, was a small laboratory study and needs further investigation. Quite likely the nutrient availability will be affected where CFA or CFA-stabilized SS results in major increase in soil pH. Overall, it seems that coapplication of CFA with SS when applied in appropriate amounts can be a useful source of major and micro-nutrients, and the complementary properties ( $\mathrm{pH}$ correction, buffering acidification following SS alone application, organic-C addition and improvements in other soil physical, chemical and biological attributes) of the mixture help bring better soil improvement compared to the use of either CFA or SS alone.

\section{Use of CFA for contaminated land remediation}

Preserving soils from degradation, particularly due to pollution by toxic metals and organic pollutants is of increasing concern. Even though many of the metals are essential in trace amounts for plants, human health and other biota, at their elevated levels due to pollution they are potentially toxic and thus present a great health and environmental risk. The risk, however, can be mitigated by controlling metal soil solubility. One of the most important methods to decrease metals solubility and hence their plant availability is liming, which increases soil $\mathrm{pH}$ and enhances metals retention in the solid phase (Hooda et al., 1997; Hooda, 2010). However, liming has several limitations. For example, it is not efficient in strongly acidic soils, as large amounts of lime are not available in many regions of the world, and mining for lime has its own environmental impact.

\subsection{Metal contaminated soils}

The use of alkaline CFA may offer an alternative way of metalcontaminated soil remediation/management via their immobilization (Kim et al., 2012). This was demonstrated in a study where CFA was used to stabilize a $\mathrm{Pb}$ - and $\mathrm{Cu}$-contaminated soil (Kumpiene et al., 2007). The results showed that soil amendment with CFA reduced the leaching of $\mathrm{Cu}$ and $\mathrm{Pb}$ by an average of $96 \%$ and $99.9 \%$ in laboratory batch experiments and by $96 \%$ and $97 \%$, respectively during the two-year field trial period. The amendment reduced the exchangeable metal forms, as estimated by different physicochemical methods, likely resulting from the formation of 
new mineral $\mathrm{Cu}$ - and $\mathrm{Pb}$-bearing phases and the enhanced metal sorption due to increased amount of sorptive sites.

The use of CFA seems to offer significant metal immobilization potential. For example, a laboratory column leaching study demonstrated that relatively small additions of CFA to contaminated soils drastically reduced the toxic metal content in the effluent (Ciccu et al., 2003). Similarly, Dermatas and Meng (2003) found that addition of CFA to metal-contaminated soils effectively reduced metals leaching well below their nonhazardous regulatory limits. One of the criticisms of such studies is that they are often short-term and lack field testing. Two recent long-term field studies by Mench et al. (2006) and Lopareva-Pohu et al. (2011) dispel at least some of such criticisms. The effectiveness of CFA for in situ remediation of a $\mathrm{Cd}$ - and $\mathrm{Ni}$-contaminated soil in a longterm field experiment was assessed by Mench et al. (2006). Seven years after treatment, CFA reduced labile fractions of $\mathrm{Cd}$ and $\mathrm{Ni}$ in the soil and restored the activity of key soil hydrolases. Another study where CFA was used to aid phytostabilisation of a site highly contaminated with PTEs showed similar results. Eight years after amending the site with CFA and planting with trees, the findings show that soil extractable $\mathrm{Cd}, \mathrm{Pb}$ and $\mathrm{Zn}$ were much lower than in the reference control, at least partly due to soil pH buffering effect of the CFA (Lopareva-Pohu et al., 2011).

The effect of CFA on metal mobility via its influence on soil $\mathrm{pH}$ was further demonstrated by Houben et al. (2012), where the CFA application reduced leaching and plant-availability of $\mathrm{Cd}, \mathrm{Zn}$ and $\mathrm{Pb}$, mainly due to increased soil $\mathrm{pH}$. The mechanism of metal stabilization in a contaminated soil by silicon-rich amendments was investigated by Gu et al. (2011). The results from their work indicated that the application of CFA ( 20 and $40 \mathrm{~g} \mathrm{~kg}^{-1}$ ) and steel slag ( 3 and $6 \mathrm{~g} \mathrm{~kg}^{-1}$ ) increased soil pH from 4.0 to 5.0 and 6.4, decreased the plant-availability of PTEs by at least $60 \%$, and further suppressed metal uptake by rice. X-ray diffraction analysis indicated the mobile elements were mainly transformed as their silicates, phosphates and hydroxides in the amended soil. Scotti et al. (1999) in a study with different soils amended with CFA found that in acidic soils the ash addition decreased $\mathrm{Zn}, \mathrm{Cu}, \mathrm{Cd}$ and $\mathrm{Ni}$ bioavailability. The data obtained suggest that the alkalizing effects of CFA can be utilized to reduce plant accumulation of PTEs, particularly in poorly buffered acidic soils. However, the use of CFA in agriculture as an amendment may cause deficiencies of some essential plant nutrients where the soil $\mathrm{pH}$ becomes too alkaline.

Coal fly ash because of its composition (alumina, silica, ferric oxide, calcium oxide, magnesium oxide and carbon, and its physical properties) is capable of retaining metals, even though it can be a significant source of them as well. This was demonstrated by Tsadilas et al. (2009c) where they compared the influence of CFA application $(0.25 \%$ and $0.5 \%, \mathrm{w} / \mathrm{w})$ on $\mathrm{Cu}$ and $\mathrm{Zn}$ sorption by an acidic soil. The distribution coefficient $\left(K_{\mathrm{d}}\right)$ values for the $0.5 \%$ treatment were about 10 and 7 times greater compared to those of the control soil for $\mathrm{Zn}$ and $\mathrm{Cu}$, respectively. Similar influence of CFA application on $\mathrm{Cd}$ and $\mathrm{Pb}$ sorption by an acidic Alfisol was also observed (Shaheen and Tsadilas, 2010). The increase in metal sorption following CFA application may also be attributed to its alkalinity and high contents of silica, alumina and iron oxides, which are strong metal sorbents (Adriano et al., 1980). This interpretation is consistent with the observations that the hydrous silicon oxide and aluminium oxide in CFA can form complexes with metal ions by chemical bonding (Pan et al., 2003). It would, therefore, appear that CFA enhances soil metal sorption through a combination of mechanisms, such as, raising soil $\mathrm{pH}$, supplying metal sorbents (e.g. silica oxide, aluminium oxide) and by increasing soil surface area. Bertocchi et al. (2006) also confirmed the high sorption capacity of $\mathrm{CFA}$ for $\mathrm{As}, \mathrm{Cd}, \mathrm{Cu}, \mathrm{Pb}$ and $\mathrm{Zn}$. The results of this investigation showed that sorption capacity is strongly influenced by $\mathrm{pH}$.

\subsection{Organic micro-pollutants contaminated soils}

Soil amendments may increase/decrease the mobility of soilapplied pesticides, thus can play a significant role in managing the risk of water resources contamination. Any amendment to soil that changes its physico-chemical properties, which in turn, can affect the sorption, transport and degradation of the soil-applied pesticides. Coal fly ash has shown significant sorption capacity for organic pollutant (Konstantinou and Albanis, 2000); therefore, its application to soil may help reduce the downward mobility of soilapplied pesticides, especially herbicides (Ghosh and Singh, 2012a). Metribuzin is used as a selective herbicide for pre-emergence and post-emergence control of annual grasses and broadleaf weeds in sugarcane, soybean, wheat, etc. Metribuzin is weakly sorbed in soils and thus has the potential of lateral and downward movement in the soil (Singh et al., 2013a,b). Majumdar and Singh (2007) studied the effect of CFA application at two rates [2.5\% (CFA1) and 5\% (CFA2), w/w] on the sorption and mobility of metribuzin in soils. Application of CFA increased the metribuzin retention in the soil. Mass balance calculation indicated that in CFA1 column, only $26 \%$ of the initially applied metribuzin was recovered in the leachate. However, after 5\% coal fly ash (CFA2) amendment, no metribuzin was recovered in the leachate. Compared to $97 \%$ leaching losses of metribuzin from the untreated soil column, leaching losses of metribuzin were reduced by $75-100 \%$ after the coal fly ash amendment. This study indicates that CFA was quite effective in reducing the downward mobility of metribuzin in packed soil columns of a sandy loam soil. These findings were further confirmed in a recent work which examined the effect of CFA amendment on metribuzin leaching from three soils (Singh et al., 2013a). Coal fly ash was applied at 1,2 and $5 \%$ levels in the upper $15 \mathrm{~cm}$ of the $30 \mathrm{~cm}$ long packed soil columns. The results suggested a considerable reduction in the leaching losses of metribuzin in CFA-amended columns of all the three soil types and the effect increased with the level of CFA applied. The high efficiency of CFA in reducing the downward mobility of metribuzin in soils might be due to its high sorption affinity, as supported by findings of $15-92 \%$ increase in metribuzin sorption by three Indian soils; the effect though varied across the two CFAs and three soils used (Singh et al., 2012). These results demonstrate that not all coal fly ashes may be effective in enhancing the sorption of metribuzin in soils to the same extent.

The sorption of metribuzin in CFA amended soils, however, is likely to affect its persistence in soil, especially under flooding conditions. For example, Singh et al. (2013b) examined the effect of CFA (1, 2 and $5 \%, w / w)$ amendment on the persistence of metribuzin in three Indian soil types. Metribuzin was more persistent in the flooded soils (predominantly anaerobic) than the non-flooded (aerobic) soils. Also, the high efficiency of CFA to sorb metolachlor and atrazine in CFA amended Inceptisol and Alfisol has been observed (Ghosh and Singh, 2012b). The findings suggested that sorption mechanism of metolachlor and atrazine involved the physical association at the sorbate surface.

Clearly the use of CFA can be considered only where excessive past pesticide application has resulted in significant pesticide accumulation. This cannot be used as normal agronomic practices such that apply CFA alongside pesticide so that pesticide leaching risk can be mitigated.

\section{Removal of PTEs and pesticides from contaminated wastewaters using CFA}

Water contamination with PTEs and pesticides represents a potential threat to humans, animals and plants even at low concentrations (Hu et al., 2012; Wang et al., 2013). As, unlike organic pollutants, PTEs are non-degradable and they can accumulate in 
Table 4

Summary of trace elements adsorption from contaminated aqueous solutions and wastewater streams by coal fly ash (CFA).

\begin{tabular}{|c|c|c|}
\hline Element & Adsorption capacity, $\mathrm{mg} \mathrm{g}^{-1}$ & References \\
\hline $\mathrm{As}^{3+}$ & $3.7-89.2$ & Pattanayak et al. (2000) \\
\hline $\mathrm{As}^{5+}$ & $\begin{array}{l}7.7-27.8 \\
0.02-34.5\end{array}$ & $\begin{array}{l}\text { Diamadopoulos et al. (1993) } \\
\text { Pattanayak et al. (2000) }\end{array}$ \\
\hline $\mathrm{Cd}^{2+}$ & $\begin{array}{l}1.6-8.0 \\
0.67-0.83 \\
0.08-0.29 \\
0.008-0.22 \\
198.2 \\
195.2 \\
180.4 \\
0.05 \\
18.98 \\
18.92\end{array}$ & $\begin{array}{l}\text { Ayala et al. (1998) } \\
\text { Bayat (2002a) } \\
\text { Bayat (2002c) } \\
\text { Bayat (2002c) } \\
\text { Apak et al. (1998) } \\
\text { Apak et al. (1998) } \\
\text { Apak et al. (1998) } \\
\text { Weng and Huang (1994) } \\
\text { Papandreou et al. (2007) } \\
\text { Papandreou et al. (2007) }\end{array}$ \\
\hline $\mathrm{Cr}^{3+}$ & $\begin{array}{l}52.6-106.4 \\
4.35 \\
41.61\end{array}$ & $\begin{array}{l}\text { Cetin and Pehlivan (2007) } \\
\text { Gupta and Ali (2004) } \\
\text { Hui et al. (2005) }\end{array}$ \\
\hline $\mathrm{Cr}^{6+}$ & $\begin{array}{l}2.92 \\
1.38 \\
1.82 \\
1.67 \\
0.55 \\
0.82 \\
4.25-4.35 \\
23.86\end{array}$ & $\begin{array}{l}\text { Panday et al. (1984) } \\
\text { Banerjee et al. (2004) } \\
\text { Banerjee et al. (2004) } \\
\text { Banerjee et al. (2004) } \\
\text { Bayat (2002c) } \\
\text { Bayat (2002c) } \\
\text { Gupta and Ali (2004) } \\
\text { Bhattacharya et al. (2008) }\end{array}$ \\
\hline $\mathrm{Cu}^{2+}$ & $\begin{array}{l}1.39 \\
1.18 \\
1.7-8.1 \\
0.34-1.35 \\
0.09-1.25 \\
207.3 \\
205.8 \\
198.5 \\
0.63-0.81 \\
0.76 \\
7.5 \\
20.92 \\
7.0 \\
178.5-249.1 \\
126.4-214.1 \\
76.7-137.1 \\
7.0\end{array}$ & $\begin{array}{l}\text { Panday et al. (1985) } \\
\text { Panday et al. (1985) } \\
\text { Ayala et al. (1998) } \\
\text { Bayat (2002b) } \\
\text { Bayat (2002b) } \\
\text { Ricou et al. (1999) } \\
\text { Ricou et al. (1999) } \\
\text { Ricou et al. (1999) } \\
\text { Lin and Chang (2001) } \\
\text { Rao et al. (2003) } \\
\text { Ricou et al. (1999) } \\
\text { Papandreou et al. (2007) } \\
\text { Hossain et al. (2005) } \\
\text { Hsu et al. (2008) } \\
\text { Hsu et al. (2008) } \\
\text { Hsu et al. (2008) } \\
\text { Gupta and Torres (1998) }\end{array}$ \\
\hline $\mathrm{Hg}^{2+}$ & $\begin{array}{l}2.82 \\
11.0 \\
12.5 \\
13.4\end{array}$ & $\begin{array}{l}\text { Sen and De (1987) } \\
\text { Banerjee et al. (2004) } \\
\text { Banerjee et al. (2004) } \\
\text { Banerjee et al. (2004) }\end{array}$ \\
\hline $\mathrm{Ni}^{2+}$ & $\begin{array}{l}10.0-15.75 \\
0.40-0.98 \\
9.0-14.0 \\
9.8-14.93 \\
0.06-1.16 \\
1.12-1.70 \\
3.9\end{array}$ & $\begin{array}{l}\text { Banerjee et al. (2003) } \\
\text { Bayat (2002b) } \\
\text { Banerjee et al. (2003) } \\
\text { Banerjee et al. (2003) } \\
\text { Bayat (2002b) } \\
\text { Gupta et al. (2003) } \\
\text { Ricou et al. (1999) }\end{array}$ \\
\hline $\mathrm{Pb}^{2+}$ & $\begin{array}{l}444.7 \\
70.6 \\
483.4 \\
437.0 \\
753.0 \\
18.8 \\
420.6\end{array}$ & $\begin{array}{l}\text { Yadava et al. (1987) } \\
\text { Gan (2000) } \\
\text { Yadava et al. (1987) } \\
\text { Yadava et al. (1987) } \\
\text { Yadava et al. (1987) } \\
\text { Diamadopoulos et al. (1993) } \\
\text { Apiratikul and Pavasant (2008) }\end{array}$ \\
\hline $\mathrm{Zn}^{2+}$ & $\begin{array}{l}6.5-13.3 \\
7.5-15.5 \\
7.0-15.4 \\
0.25-2.8 \\
0.25-1.19 \\
0.07-1.30 \\
2.34-2.54 \\
13.21 \\
4.64\end{array}$ & $\begin{array}{l}\text { Banerjee et al. (2003) } \\
\text { Banerjee et al. (2003) } \\
\text { Banerjee et al. (2003) } \\
\text { Bayat (2002a) } \\
\text { Bayat (2002b) } \\
\text { Bayat (2002b) } \\
\text { Gupta and Ali (2000) } \\
\text { Gupta and Sharma (2003) } \\
\text { Weng and Huang (1990) }\end{array}$ \\
\hline
\end{tabular}

Table 4 (continued)

\begin{tabular}{lll}
\hline Element & Adsorption capacity, $\mathrm{mg} \mathrm{g}^{-1}$ & References \\
\hline 0.27 & Weng and Huang (1994) \\
$0.07-0.75$ & Weng and Huang (2004) \\
3.4 & Ricou et al. (1999) \\
11.11 & Gupta and Torres (1998) \\
7.03 & Ho et al. (1989) \\
\hline
\end{tabular}

living tissues; therefore, they must be removed from wastewater streams before their discharge in order to meet increasingly stringent environmental quality standards (Gupta et al., 2009; Hashim et al., 2011; Shaheen et al., 2013). The removal of PTEs and pesticides from contaminated wastewater has thus received much attention (Shaheen et al., 2013).

Despite the availability of a number of cleanup technologies for organic and inorganic chemicals contaminated wastewaters, adsorption approaches still attract much attention. Certain industrial waste products may have potential as inexpensive metal and pesticides sorbents (Bailey et al., 1999; Gupta et al., 2002; Babel and Kurniawan, 2003; Lu et al., 2005; Karatas, 2012; Shaheen et al., 2013). Activated charcoal is the most commonly used sorbent for removing pesticide residue from contaminated waters (Jiang et al., 2006; Lopez-Ramon et al., 2007). However, because of the high cost of activated charcoal, its use at large scale is very limited. In order to overcome this problem, exploitation of newer, cheaper and indigenous waste materials for the removal of pesticides and other contaminants from wastewaters have been the focus of recent research.

Many studies have examined non-conventional alternative sorbents produced from renewable and low-cost resources in terms of their effectiveness compared to the traditional synthetic ion exchangers (Hasany and Ahmad, 2006; Shaheen et al., 2012b, 2013; Badruddoza et al., 2013). One of such alternative sorbents is CFA, which has received special attention as an economical sorbent for removing trace elements from wastewater due to its abundance and easy availability. Numerous studies on the efficiency of CFA on the sorption and removal of PTEs from aqueous solutions and wastewater streams (Gupta and Torres, 1998; Weng and Huang, 2004; Alinnor, 2007; Pehlivan and Cetin, 2007; Wang et al., 2007; Aydin et al., 2008; Koukouzas et al., 2010) have shown that CFA can be used in wastewater treatment because of its major chemical components such as alumina, silica, ferric oxide, calcium oxide, magnesium oxide, and carbon, and its physical properties, such as fine particle size and high surface area, which together make CFA a strong sorbent of both organic and inorganic contaminants.

Table 4 summarizes results of the use of CFA for PTEs removal from wastewaters. Comparisons of CFA with other nonconventional sorbents show that CFA is a good sorbent and can be used effectively for the treatment of metal rich wastewaters. Wang and Wu (2006), Fu and Wang (2011) and Ahmaruzzaman (2011) have reviewed the environmental benign utilization of CFAs as low-cost sorbents for the removal of various pollutants from wastewaters. From the studies summarized in Table 4, it is clear that CFA is a promising sorbent for PTEs removal from wastewater streams.

Coal fly ash is also being considered as a sorbent for the removal of various organic pollutants from wastewaters (Wang and $\mathrm{Wu}$, 2006). Many reports have highlighted the pesticide sorption potential of CFA (e.g., Konstantinou and Albanis, 2000; Majumdar and Singh, 2007) and have recommended it for removal of pesticides from wastewaters (Alam et al., 2000; Gupta and Ali, 2001; Lu et al., 2005; Akhtar et al., 2007; Sharma et al., 2008). The results of these studies indicate that the use of CFA for pesticides removal from industrial and agricultural wastewaters can be useful. Also, the 
removal of other micro-organic pollutants from wastewater using CFA has been reviewed by Ahmaruzzaman (2009). It is evident from this review that CFA has demonstrated good removal capabilities for various organic chemicals. Comparisons of the pesticide removal efficiency of CFA with other low cost sorbents show that it is highly effective. For example, Sharma et al. (2008) suggest that CFA is capable of removing pesticides from aqueous solution, and that at low pesticide concentrations $\left(<10 \mu \mathrm{g} \mathrm{ml}^{-1}\right)$ it can remove more than $99 \%$ of the contaminant.

After remediation, options for resultant ash sludge treatment can include landfilling, incineration, stabilization and cementbased solidification. Chemical extraction, supercritical fluid extraction, bioleaching and electro-kinetic processes in removing metals from contaminated CFA sludge have also been considered. Whilst the use of CFA in wastewater treatment is a promising technology, the disposal of spent-ash sludge can be problematic, as its landfilling is not sustainable.

\section{Discussion and conclusions}

Coal fly ash being a by-product of coal-fired power production is generated in massive amounts - globally some 750 million tons per year (Pandey and Singh, 2010). To meet the ever increasing global electricity demand the use of coal for power production is increasing year-on-year at a considerable rate and is projected to increase further, with similar trends in CFA generation. A 50\% increase in CFA generation between 2005 and 2010 is a testimony of the increasing use of coal for power production and the resulting waste.

Coal fly ash in the US or EU member states is not classified as hazardous waste because CFA and other coal combustion byproducts have not been found to exhibit any of the characteristics of hazardous waste: corrosivity, reactivity, ignitability and toxicity (Feuerborn, 2011). This has allowed widespread utilization of CFA in construction industry (e.g. manufacturing cement, concrete production, embankments and other structural fills, and brick manufacturing), which is highly useful and provides an effective replacement of natural resources. Likewise, CFA is commonly used for geotechnical (soil-stabilisation, road construction) and land restoration (open cast mines, quarries and pits) purposes. However, there are no clear regulations, specifications or guidelines for CFA use in agriculture, e.g. some US states regulate it but their guidelines vary. This lack of legislation or guidelines is one of the major barriers to the use of CFA for general soil improvement purposes (Ahmaruzzaman, 2010). Other barriers to the use of CFA in agriculture include distance of the source from the place of use. Consequently, a considerable amount of CFA however remains unutilized, stored around coal-fired power stations. This situation causes soil and water pollution, albeit on a local scale. The storage of CFA in lagoons and/or land filling is not environmentally sustainable, particularly when its generation in increasing amounts is a continuous process. This has generated much interest in finding alternative options for the disposal of unutilized CFA.

CFAs usually contain a number of beneficial nutrients and potentially harmful contaminants (e.g. metals, PCBs, PAHs). The use of CFA for soil improvements can make it a useful resource but it does represent some risk of soil and water contamination with PTEs and organic contaminants. As a result, the use of CFA for soil improvement has received much scientific attention in the last three decades (e.g., Adriano et al., 1980; El-Mogazi et al., 1988; Yunusa et al., 2006; Ukwattage et al., 2013; Skousen et al., 2013; Ram and Masto, 2014).

There is no doubt that CFA application as amendment is beneficial in a number of ways, as it can improve soil physical conditions, e.g. water infiltration, soil water holding capacity, hydraulic conductivity, bulk density and soil aggregation (Adriano et al., 1980; Pathan et al., 2003; Singh et al., 2010; Ukwattage et al., 2013; Skousen et al., 2013). It can also help alleviate soil compaction and improve aggregate stability of sodic soils (Kumar and Singh, 2003); can supplement useful plant nutrients, e.g. P, Ca, S, and $\mathrm{Mg}, \mathrm{K}, \mathrm{Fe}, \mathrm{Mn}, \mathrm{Zn}, \mathrm{Cu}$, and B (Sajwan et al., 2003) and can help correct acidic pH conditions (Ciccu et al., 2003; Shaheen and Tsadilas, 2010). It is important to stress that soil and CFA properties need to be carefully considered as incorrect use of CFA may not prove beneficial and possibly may cause adverse effects including toxicity (e.g. when acidic CFA is used in acidic soil or too large amounts are applied) (e.g. Jala and Goyal, 2006; Patra et al., 2012a; Ukwattage et al., 2013; Skousen et al., 2013; Ram and Masto, 2014). Clearly, best outcomes in terms of soil improvements are likely only either in soils which have undergone a considerable degree of (physical and or chemical) degradation or those which are inherently not fertile. Such CFA soil applications should be accompanied by appropriate amounts of $\mathrm{N}$ and $\mathrm{P}$ inputs, as CFA contains very little or no $\mathrm{N}$ and plant availability of CFA-borne $\mathrm{P}$ is limited. These two nutrients ( $\mathrm{N}$ and $\mathrm{P}$ ) can be supplemented by using chemical fertilizers or manures - the latter would be more beneficial, as it would also add much needed organic carbon in such soils (Page et al., 1979; Adriano et al., 1980; Ram and Masto, 2014). Clearly co-application of CFA with organic and inorganic amendments offers many advantages in terms of nutrient availability, $\mathrm{pH}$ buffering, organic matter addition, and overall general soil improvement.

Co-application of CFA with sewage sludge (SS) can be particularly beneficial for soil improvements and at the same time it offers a sensible means of disposal of both CFA and SS, which are produced in large amounts. While both contain nutrients and contaminants, and SS application is often regulated by metal loadings, the mobility and hence environmental risk of SS-bone metals usually increases once SS breaks down (Hooda and Alloway, 1993; Sajwan et al., 2003; Hooda, 2010). Co-application of CFA with SS, particularly that of alkaline reaction can help mitigate this risk, and at the same time it, i.e. SS supplies much needed N, P and C compared to CFA alone application. Such a co-application is particularly useful in the restoration of soils affected by acid mine drainage (AMD), where a mixture of alkaline CFA and SS can help neutralize AMD and thus stabilize mining-mobilized metals, supply all essential nutrients, including organic carbon and ultimately can help establish an effective plant cover and restore the site (Misra et al., 1996; Iyer and Scott, 2001; Xenidis et al., 2002).

Likewise, the use of alkaline CFA is likely to help in the remediation of metal contaminated sites by immobilization of metals via raising soil $\mathrm{pH}$ and formation of stable metal phases (Hooda and Alloway, 1996; Hooda et al., 1997; Mench et al., 2006; Hooda, 2010; Lopareva-Pohu et al., 2011; Kim et al., 2012; Skousen et al., 2013; Ram and Masto, 2014). However, it is important that such a use of CFA should not lead to further elevation of total metal levels in the soils. Since CFA is a strong sorbent, it has the potential for effective removal of PTEs and pesticides from wastewater streams. This, while can be a cost-effective means of wastewater treatment, it presents challenges in terms of disposal of the spent CFA, which would have much increased contaminants load (Ahmaruzzaman, 2010).

Constraints to the use of CFA as soil amendment could be both insufficient or excessive amounts of $\mathrm{CaCO}_{3}, \mathrm{CaO}$, and/or $\mathrm{Ca}(\mathrm{OH})_{2}$ in raising soil $\mathrm{pH}$ insufficiently or too much; its high $\mathrm{B}$ content can induce B toxicity in plants (Tolle and Arthrur, 1983; Aitken et al., 1984); inhibition of microbial respiration and enzyme activity, resulting from its possible adverse effects on soil conditions (Pandey and Singh, 2010). Excessive CFA-borne sulphur can be toxic to plants, and excessive amounts of undesirable PTEs e.g. As, $\mathrm{Cd}, \mathrm{Cr}$, Ni, Pb, B and Se (Sajwan et al., 2003; Ram and Masto, 2014) and 
organic contaminants (PAHs and PCBs) could potentially contaminate water and pose toxicity to plants, animals and microorganisms (Sahu et al., 2009).

It should be stressed here that these potential problems can be mitigated by applying appropriate amounts of CFA, considering site specific conditions. Thus, most constraints should not impose problems in CFA use for soil improvements, provided the suitability of CFA is evaluated beforehand and suitable application rates are worked out. Whilst there is a lack of regulations or guidelines, the use of CFA for soil improvement should not exceed soil contaminant loadings as permitted for other wastes, e.g. sewage sludge. Excess application of CFA to soils is likely to offset its positive effects. This review emphasizes that selection of CFA for specific problems is to be based on the consideration of both the nature and properties of the soil and CFA. Furthermore, whilst the levels of organic contaminants in CFA (e.g. PCBs and PAHs) seem to be similar or lower than those permitted for land disposal of other wastes e.g. SS, further work is required on the persistence of such CFA-borne organic contaminants. Nonetheless, CFA application should not result in significant elevation of such contaminants, provided used prudently.

\section{Acknowledgements}

We categorically acknowledge that this work was not funded by the electricity industry or any organisation with interest in coal combustion by-products. We would like to thank our respective institutions for funding this work.

\section{References}

Adriano, C.D., Weber, J.T., 2001. Influence of fly ash on soil physical properties and turf grass establishment. J. Environ. Qual. 30, 596-601.

Adriano, D.C., Woodford, T.A., Ciravolo, T.G., 1978. Growth and elemental composition of corn and bean seedlings as influenced by soil application of coal ash. J. Environ. Qual. 7, 416-421.

Adriano, D.C., Page, A.L., Elseewi, A.A., Chang, A.C., Straughan, I., 1980. Utilization and disposal of fly ash and other coal residues in terrestrial ecosystems: a review. J. Environ. Qual. 9, 333-344.

Adriano, D.C., Weber, J., Bolan, N., Paramasivam, S., Koo, B.J., Sajwan, K.S., 2002. Effects of high rates of coal fly ash on soil, turfgrass and groundwater quality. Water Air Soil Pollut. 139, 365-385.

Ahmaruzzaman, M., 2009. Role of fly ash in the removal of organic pollutants from wastewater. Energy Fuel 23, 1494-1511.

Ahmaruzzaman, A., 2010. A review of the utilization of fly ash. Prog. Energy Combust. Sci. 36, 327-363.

Ahmaruzzaman, M., 2011. Industrial wastes as low-cost potential adsorbents for the treatment of wastewater laden with heavy metals. Adv. Colloid. Interf. 166, 36-59.

Aitken, R.L., Campbell, D.J., Bell, L.C., 1984. Properties of Australian fly ash relevant to their agronomic utilization. Aust. J. Soil Res. 22, 443-453.

Akhtar, M., Hasany, S.M., Bhanger, M.I., Iqbal, S., 2007. Low cost sorbents for the removal of methyl parathion pesticide from aqueous solutions. Chemosphere 66, 1829-1838.

Alam, J.B., Dikshit, A.K., Bandyopadhyay, M., 2000. Efficacy of adsorbents for removal of 2,4-D and atrazine from water environment. Global Nest Int. J. 2, 139-148.

Alinnor, I.J., 2007. Adsorption of heavy metal ions from aqueous solution by fly ash. Fuel 86, 853-857.

Alonso, J.L., Wesche, K., 1991. Characterization of fly ash. In: Wesche, K. (Ed.), Fly Ash in Concrete Properties and Performance. E \& FN SPON - An Imprint of Chapman \& Hall, pp. 3-23.

Apak, R., Tutem, E., Hugul, M., Hizal, J., 1998. Heavy metal cation retention by unconventional sorbents (red muds and fly ashes). Water Res. 32, 430-440.

Apiratikul, R., Pavasant, P., 2008. Sorption of $\mathrm{Cu}^{2+}, \mathrm{Cd}^{2+}$, and $\mathrm{Pb}^{2+}$ using modified zeolite from coal fly ash. Chem. Eng. J. 144, 245-258.

Asokan, P., Saxena, M., Bose, S.K.Z., Khazenchi, A.C., 1995. In: Proceedings of Workshop on Fly Ash Management in the State of Orissa. R.R.L., Bhubaneswar, India, pp. 64-75.

Ayala, J., Blanco, F., Garcia, P., Rodriguez, P., Sancho, J., 1998. Australian fly ash as heavy metals renoval material. Fuel 77, 1147-1154.

Aydin, H., Bulut, Y., Yerlikay, C., 2008. Removal of copper (II) from aqueous solution by adsorption onto low-cost adsorbents. J. Environ. Manage. 87, 37-45.

Babel, S., Kurniawan, T.A., 2003. Low-cost adsorbents for heavy metals uptake from contaminated water: a review. J. Hazard. Mater. 97, 219-243.
Badruddoza, A.M., Shawon, Z.B., Tay, W.D., Hidajat, K., Uddin, M.S., 2013. $\mathrm{Fe}_{3} \mathrm{O}_{4}$ cyclodextrin polymer nanocomposites for selective heavy metals removal from industrial wastewater. Carbohyd. Polym. 91, 322-332.

Bagnoli, F., Bianchi, A., Ceccarini, A., Fuoco, R., Giannarelli, S., 2005. Trace metals and organic pollutants in treated and untreated residues from urban solid waste incinerators. Microchem. J. 79, 291-297.

Bailey, S.E., Olin, T.J., Bricka, R.M., Adrian, D.D., 1999. A review of potentially low-cost sorbents for heavy metals. Water Res. 33, 2469-2479.

Banerjee, S.S., Jayaram, R.V., Joshi, M.V., 2003. Removal of Nickel (II) and Zinc (II) from wastewater using fly ash and impregnated fly ash. Sep. Sci. Technol. 38 1015-1032.

Banerjee, S.S., Joshi, M.V., Jayaram, R.V., 2004. Removal of Cr(VI) and Hg(II) from aqueous solutions using fly ash and impregnated fly ash. Sep. Sci. Technol. 39 $1611-1629$.

Basu, M., Pande, M., Bhadoria, P.B.S., Mahapatra, S.S., 2009. Potential fly-ash utilization in agriculture: a global review. Prog. Nat. Sci. 19, 1173-1186.

Bayat, B., 2002a. Combined removal of zinc (II) and cadmium (II) from aqueous solutions by adsorption onto high-calcium Turkish fly ash. Water Air Soil Pollut. 136, 69-92.

Bayat, B., 2002b. Comparative study of adsorption properties of Turkish fly ashes: I The case of nickel(II), copper(II) and zinc(II). J. Hazard. Mater. 95, 251-273.

Bayat, B., 2002c. Comparative study of adsorption properties of Turkish fly ashes: II. The case of chromium (VI) and cadmium (II). J. Hazard. Mater. 95, 275-290.

Bergmann, W., 1993. Ernärungstörungen bei Kulturpflanzen. Auflage, Gustav Fisher Verlag Jena, Stuttgart, p. 835.

Berset, J.D., Etter-Holzer, R., 1999. Quantitative determination of polycyclic aromatic hydrocarbons, polychlorinated biphenyls and organochlorine pesticides in sewage sludges using supercritical fluid extraction and mass spectrometric detection. J. Chromatogr. A 852, 545-558.

Bertocchi, A.F., Marcello, G., Roberto, P., Antonio, Z., 2006. Red mud and fly ash for remediation of mine sites contaminated with $\mathrm{As}, \mathrm{Cd}, \mathrm{Cu}, \mathrm{Pb}$ and $\mathrm{Zn}$. J. Hazard. Mater. 134, 112-119.

Bhattacharjee, U., Kandpal, T., 2002. Potential of flyash utilisation in India. Energy 27, 151-158.

Bhattacharya, A.K., Naiya, T.K., Mandal, S.N., Das, S.K., 2008. Adsorption, kinetics and equilibrium studies on removal of $\mathrm{Cr}(\mathrm{VI})$ from aqueous solutions using different low-cost adsorbents. Chem. Eng. J. 137, 529-541.

Bhumbla, D.K., Singh, R.N., Keeker, R.F., 1991. Water quality from surface mined land reclaimed with fly ash. In: Proceedings of the 9th Ash Use Symposium, American Coal Ash Association, vol. 57, pp. 1-22.

Blanchard, M., Teil, M.J., Ollivon, D., Legenti, L., Chevreuil, M., 2004. Polycyclic aromatic hydrocarbons and polychlorobiphenyls in wastewaters and sewage sludges from the Paris area (France). Environ. Res. 95, 184-197.

Blissett, R.S., Rowson, N.A., 2012. A review of the multi-component utilisation of coal fly ash. Fuel 97, 1-23.

Callén, M.S., de la Cruz, M.T., Marinov, S., Murillo, R., Stefanova, M., Mastral, A.M. 2007. Flue gas cleaning in power stations by using electron beam technology, influence on PAH emissions. Fuel Process Technol. 88, 251-258.

Carlson, C.L., Adriano, D.C., 1993. Environmental impacts of coal combustion residues. J. Environ. Qual. 22, 227-247.

Cetin, C., Pehlivan, E., 2007. The use of fly ash as a low cost, environmentally friendly alternative to activated carbon for the removal of heavy metals from aqueous solutions. Colloids Surf. A Physicochem. Eng. Aspect 298, 83-87.

Chang, A.C., Lund, L.J., Page, A.L., Warneke, J.E., 1977. Physical properties of fly ash amended soils. J. Environ. Qual. 6, 267-270.

Chevreuil, M., Granier, L., Chesterikoff, A., Letolle, R., 1990. Polychlorinated biphenyls partitioning in waters from river, filtration plant and wastewater plant: the case for Paris (France). Water Res. 24, 1325-1333.

Ciccu, R., Ghiani, M., Serci, A., Fadda, S., Peretti, R., Zucca, A., 2003. Heavy meta immobilization in the mining-contaminated soils using various industrial wastes. Miner. Eng. 16, 187-192.

Ciravolo, T.G., Adriano, D.C., 1979. Utilization of coal ash by crops under greenhouse conditions. In: Wali, M.K. (Ed.), Ecology and Coal Resource Development, vol. 2 Permagon Press, New York, pp. 958-966.

Clark, R.B., Ritchey, K.D., Baligar, V.C., 2001. Benefits and constraints for use of FGD products on agriculture land. Fuel 80, 821-828.

Clement, B., Karasek, S., 1982. Distribution of organic compound adsorbed on sizefractionated municipal incinerator fly-ash particles. J. Chromatogr. A 234 395-405.

Demeyer, A., VoundiNkana, J.C., Verloo, M.G., 2001. Characteristics ofwood ash and influence on soil properties and nutrient uptake: an overview. Bioresour Technol. 77, 287-295.

Dermatas, D., Meng, X., 2003. Utilization of fly ash for stabilization/solidification of heavy metal contaminated soils. Eng. Geol. 70, 377-394.

Dewan, S., 2008. Tennessee ash flood larger than initial estimate, The New York Times. http://www.nytimes.com/2008/12/27/us/27sludge.html.

Dhadse, S., Kumari, P., Bhagia, L.J., 2008. Fly ash characterization, utilization and government initiatives in India - a review. J. Sci. Ind. Res. 67, 11-18.

Diamadopoulos, E., Loannidis, S., Sakellaropoulos, G.P., 1993. As(V) removal from aqueous solutions by fly ash. Water Res. 27, 1773-1777.

Dudas, M.J., Warren, C.J., 1987. Submicroscopic model of fly ash particles. Geoderma 40, 101-114.

Dwivedi, D., Tripathi, R.D., Srivastava, S., Mishra, S., Shukla, M.K., Tiwari, K.K., Singh, R., Rai, U.N., 2007. Growth performance and biochemical responses of 
three rice (Oryzasativa L.) cultivars grown in fly-ash amended soil. Chemosphere 67, 140-151.

Eichler-Löbermann, B., Schiemenz, K., Makadi, M., Vago, I., Köeppen, D., 2008. Nutrient cycling by using residues of bioenergy production - II. Effects of biomass ashes on plant and soil parameters. Cereal Res. Commun. 36, 1259-1262.

El-Mogazi, D., Lisk, D.J., Weinstein, L.H., 1988. A review of physical, chemical, and biological properties of fly ash and effects on agricultural ecosystems. Sci. Total Environ. 74, 1-37.

Elfving, D.C., Bache, C.A., Gutenmann, W.H., Lisk, D.J., 1981. Analysis of crops grown on waste amended soils. Biocycle 12, 44-47.

Eljarrat, E., Caixach, J., Rivera, J., 2003. A comparison of TEQ contributions from PCDDS, PCDFs, and dioxin-like PCBs in sewage sludges from Catalonia, Spain. Chemosphere 51, 595-601.

Elseewi, A.A., Page, A.L., Grimm, S.R., 1980a. Chemical characterization of fly ash aqueous systems. J. Environ. Qual. 9, 424-428.

Elseewi, A.A., Straughan, I.R., Page, A.L., 1980b. Sequential cropping of fly ash amended soils. Effects on soil chemical properties and yield and elemental composition of plants. Sci. Total Environ. 15, 247-259.

Elseewi, A.A., Grimm, S.R., Page, A.L., Straughan, I.R., 1981. Boron enrichment of plants and soils treated with coal ash. J. Plant Nutr. 3, 409-427.

Erich, M.S., 1991. Agronomic effectiveness of wood ash as a source of phosphorus and potassium. J. Environ. Qual. 20, 576-581.

Erich, M.S., Ohno, T., 1992. Phosphorus availability to corn from wood ash amended soils. Water Air Soil Pollut. 64, 475-485.

Fail, J.L., Wochok, Z.S., 1977. Soybean growth on fly ash amended strip mine spoils. Plant Soil 48, 473-484.

Fangmark, I.B., Stromberg, B., Berge, N., Rappe, C., 1995. The influence of fly ash load and particle size on the formation of PCDD, PCDF, PCBz and PCB in a pilot incinerator. Waste Manag. Res. 13, 259-272.

Feuerborn, H.J., 2011. Coal combustion products in Europe - an update on production and utilization, standardisation and regulation. World Coal Ash Conference, May 9-12, 2011, Dever, CO, USA. http://www.flyash.info.

Frost, P., Camenzind, R., Magert, A., Bonjour, R., Karlaganis, G., 1993. Organic micropollutants in Swiss sewage sludge. J. Chromatogr. A 643, 379-388.

Fu, F., Wang, Q., 2011. Removal of heavy metal ions from wastewaters: a review. J. Environ. Manage. 92, 407-418.

Gan, Q., 2000. A case study of microwave processing of metal hydroxide sediment sludge from printed circuit board manufacturing wash water. Waste Manage. 20, 695-701.

Ghosh, R.K., Singh, N., 2012a. Managing metolachlor and atrazine leaching losses using lignite fly ash. Ecotox. Environ. Safe 84, 243-248.

Ghosh, R.K., Singh, N., 2012b. Sorption of metolachlor and atrazine in fly ash amended soils: comparison of optimized isotherm models. J. Environ. Sci. Health B 47, 718-727.

Gohda, A., Hatano, H., Hanal, T., Miyaji, K., Takahashi, N., et al., 1993. GC and GC-MS analysis of polychlorinated dioxins, dibenzofurans and aromatic hydrocarbons in fly ash from coal-burning works. Chemosphere 27, 9-15.

Gorman, J.M., Sencindiver, J.C., Horvath, D.J., Singh, R.N., Keefer, R.F., 2000. Erodibility of fly ash used as a topsoil substitute in mineland reclamation. J. Environ. Qual. 29, 805-811.

Gratima, E., Mwrinyihija, M., Killham, K., 2005. Assessment of pulverized fly ash (PFA) as an ameliorant of lead contaminated soils. Am. J. Environ. Sci. 1, 230-238.

Gu, H., Hao, Q., Tian, T., Shu-Shun, Z., Teng-Hao-Bo, D., Rufus, L.C., Shi-Zhong, W., YeTao, T., Jean-Louis, M., Rong-Liang, Q., 2011. Mitigation effects of silicon rich amendments on heavy metal accumulation in rice (Oryza sativa L.) planted on multi-metal contaminated acidic soil. Chemosphere 83, 1234-1240.

Gupta, V.K., Ali, I., 2001. Removal of DDD and DDE from wastewater using bagasse fly ash, a sugar industry waste. Water Res. 35, 33-40.

Gupta, V.K., Ali, I., 2004. Removal of lead and chromium from wastewater using bagasse fly ash-a sugar industry waste. J. Colloid Interf. Sci. 271, 321-328.

Gupta, V.K., Sharma, S., 2003. Removal of zinc from aqueous solutions using bagasse fly ash-a low cost adsorbent. Ind. Eng. Chem. Res. 42, 6619-6624.

Gupta, A., Sinha, S., 2009. Growth and metal accumulation response of Vigna radiate L. var PDM 54 (mung bean) grown on fly ash-amended soil: effect on dietary intake. Environ. Geochem. Health 31, 463-473.

Gupta, G., Torres, N., 1998. Use of fly ash in reducing toxicity of and heavy metals in wastewater effluent. J. Hazard. Mater. 57, 243-248.

Gupta, V.K., Ali, I., 2000. Utilisation of bagasse fly ash (a sugar industry waste) for the removal of copper and zinc from wastewater. Sep. Purif. Technol. 18, 131-140.

Gupta, V.K., Jain, C.K., Ali, I., Chandra, S., Agarwal, S., 2002. Removal of lindane and malathion from wastewater using bagasse fly ash - a sugar industry waste. Water Res. 36, 2483-2490.

Gupta, V.K., Ali, I., Jain, C.K., Sharma, M., Saini, V.K., 2003. Removal of cadmium and nickel from wastewater using bagasse fly ash - a sugar industry waste. Water Res. 37, 4038-4044.

Gupta, D.K., Rai, U.N., Rudra, D., Tripathi, I.M., 2004. Impacts of fly-ash on soil and plant responses. J. Plant Res. 115, 401-409.

Gupta, A.K., Sinha, S., 2006. Role of Brassica juncea (L.) Czern. (var. Vaibhav) in the phytoextraction of Ni from soil amended with fly ash: selection of extracting for metal bioavailability. J. Hazard. Mater. 136, 371-378.

Gupta, V.K., Carrott, P.M., Ribeiro, C., Suhas, M.L., 2009. Low-cost adsorbents: growing approach to wastewater treatment - a review. Crit. Rev. Environ. Sci. Technol. 39, 783-842.
Harrison, E.Z., Oakes, S.R., Hysell, M., Hay, A., 2006. Organic chemicals in sewage sludges. Sci. Total Environ. 367, 481-497.

Hasany, S.M., Ahmad, R., 2006. The potential of cost-effective coconut husk for the removal of toxic metal ions for environmental protection. J. Environ. Manage. 81, 286-295.

Hashim, M.A., Mukhopadhyay, S., Sahu, J., Sengupta, B., 2011. Remediation technologies for heavy metal contaminated groundwater. J. Environ. Manage. 92, 2355-2388.

Haynes, R.J., 2009. Reclamation and revegetation of fly ash disposal sites - challenges and research needs. Rev. J. Environ. Manage. 90, 43-53.

Hill, M.J., Lamp, C.A., 1980. Use of pulverized fuel ash from Victorian brown coal as a source of nutrients for pasture species. Aust. J. Exp. Agric. Anim. Husb. 20, $377-384$.

Ho, G.E., Mathew, K., Newman, P.W.G., 1989. Leachate quality from gypsum neutralized red mud applied to sandy soils. Water Air Soil Pollut. 47, 1-18.

Hodgson, R., Dyer, D., Brown, D.A., 1982. Neutralization and dissolution of high calcium fly ash. J. Environ. Qual. 11, 93-98.

Hooda, P.S., 2010. Trace Elements in Soils, first ed. John Wiley \& Sons Ltd., Chichester, United Kingdom.

Hooda, P.S., Alloway, B.J., 1996. The effect of liming on heavy metal concentrations in wheat, carrots and spinach. J. Agric. Sci. Camb. 127, 289-294.

Hooda, P.S., Alloway, B.J., 1993. Effects of time and temperature on the bioavailability of $\mathrm{Cd}$ and $\mathrm{Pb}$ from sludge-amended soils. J. Soil Sci. 44, 97-110.

Hooda, P.S., McNaulty, D., Alloway, B.J., Aitken, M.N., 1997. Plant availability of heavy metals in soils previously amended with sewage sludges. J. Sci. Food Agric. 73, $446-454$.

Hossain, M.A., Kumita, M., Michigami, Y., More, S., 2005. Optimaization of parameters for adsorption on used blak tea leaves. Adsorption 11, 561-568.

Houben, D., Pircar, J., Sonnet, P., 2012. Heavy metal immobilization by cost-effective amendments in a contaminated soil: effects on metal leaching and phytoavailability. J. Geochem. Explor. 123, 87-94.

Hsu, T.C., Yu, C.C., Yeh, C.M., 2008. Adsorption of $\mathrm{Cu}^{2+}$ from water using raw and modified coal fly. Fuel 87, 1355-1359.

Hu, M., Shujuan, Z., Bingcai, P., Weiming, Z., Lu, L., Quanxing, Z., 2012. Heavy metal removal from water/wastewater by nanosized metal oxides: a review. J. Hazard. Mater. 211-212, 317-331.

Hui, K.K., Chao, C.Y., Kot, S.C., 2005. Removal of mixed heavy metal ions in wastewater by zeolite $4 \mathrm{~A}$ and residual products from recycled coal fly ash. J. Hazard. Mater. 127, 89-101.

Hytönen, J., 2003. Effects of wood, peat and coal ash fertilization on Scots Pine foliar nutrient concentrations and growth on afforested former agricultural peat soils. Silva Fenn. 37, 219-234.

International Energy Statistics, 2011. US Energy Information Administration. http:// www.eia.gov/cfapps/ipdbproject/iedindex3.cfm.

Iyer, R.S., Scott, J.A., 2001. Power station fly ash e a review of value-added utilization outside of the construction industry. Resour. Conserv. Recyc. 31, 217-228.

Jala, S., Goyal, D., 2006. Fly ash as a soil ameliorant for improving crop production a review. Bioresour. Technol. 97, 1136-1147.

Jamil, M., Qasim, M., Umar, M., Subhan, A., 2004. Impact of organic wastes (bagasse ash) on the yield of wheat (Triticum aestivum L.) in a calcareous soil. Int. J. Agric. Biol. 6, 468-470.

Jiang, H., Adams, C., Grazino, N., Roberson, A., Mac Guire, M., Khiari, D., 2006 Occurrence and removal of chloro-s-triazine in water treatment plants. Environ. Sci. Technol. 40, 3609-3616.

Kabata-Pendias, A., 2011. Trace Elements in Soils and Plants, fourth ed. CRC Press, Boca Raton, USA.

Karatas, M., 2012. Removal of Pb(II) from water by natural zeolitic tuff: kinetics and thermodynamics. J. Hazard. Mater. 199-200, 383-389.

Katsoyiannis, A., Samara, C., 2004. Persistent organic pollutants (POPs) in the sewage treatment plant of Thessaloniki, northern Greece: occurrence and removal. Water Res. 38, 2685-2698.

Khan, M.R., Khan, M.W., 1996. The effect of fly ash on plant growth and yield of tomato. Environ. Pollut. 92, 105-111.

Khan, M.R., Singh, W.N., 2001. Effects of soil application of fly ash on the fusarial wilt on tomato cultivars. Int. J. Pest. Manag. 47, 293-297.

Kim, B.Y., Jung, G.B., Lim, S.U., Park, J.H., 1994. Influence of fly ash application on content of heavy metals in the soil. II. Content change by the successive application. J. Korean Soc. Soil Sci. Fert. 27, 72-77.

Kim, B.J., Back, J.H., Kim, Y.S., 1997. Effect of fly ash on the yield of Chinese cabbage and chemical properties of soil. J. Korean Soc. Soil Sci. Fert. 30, 161-167.

Kim, K., Kim, J., Park, J., Kim, M., Owens, G., Youn, G., Lee, J., 2012. Immobilizerassisted management of metal-contaminated agricultural soils for safer food production. J. Environ. Manage. 102, 88-95.

Konstantinou, I.K., Albanis, T.A., 2000. Adsorption-desorption studies of selected herbicides in soil-fly ash mixtures. J. Agric. Food Chem. 48, 4780-4790.

Koukouzas, N., Charalampos, V., Grigorios, I., Ioannis, M., Angeliki, M. 2010. Removal of heavy metals from wastewater using CFB-coal fly ash zeolitic materials. J. Hazard. Mater. 173, 581-588.

Kumar, K.V., Patra, D.D., 2012. Alteration in yield and chemical composition of essential oil of Mentha piperita L. plant: effect of fly ash amendments and organic wastes. Ecol. Eng. 47, 237-241.

Kumar, D., Singh, B., 2003. The use of coal fly ash in sodic soil reclamation. Land Degrad. Dev, 14, 285-299.

Kumpiene, J., Lagerkvist, A., Maurice, C., 2007. Stabilization of $\mathrm{Pb}-$ and Cucontaminated soil using coal fly ash and peat. Environ. Pollut. 145, 365-373. 
Lazzari, L., Sperni, L., Bertin, P., Pavoni, B., 2000. Correlation between inorganic (heavy metals) and organic (PCBs and PAHs) micropollutant concentrations during sewage sludge composting processes. Chemosphere 41, 427-435.

Lee, H., Ha, H., Lee, C.H., Lee, Y.B., Kim, P.J., 2006. Fly ash effect on improving soil properties and rice productivity in Korean paddy soils. Bioresour. Technol. 97, 1490-1497.

Lin, C.J., Chang, J.E., 2001. Effect of fly ash characteristics on the removal of $\mathrm{Cu}(\mathrm{II})$ from aqueous solution. Chemosphere 44, 1185-1192.

Lin, C.S., Ho, P.S., 2003. China's resources and land-use change: insights from the 1996 land survey. Land Use Policy 20, 87-107.

Lior, N., 2010. Sustainable energy development: the present 2009. Situation and possible paths to the future. Energy 35, 3976-3994.

Liu, K., Xie, W., Zhao, Z.-B., Pan, W.-P., Rilley, J.T., 2000. Investigation of polycyclic aromatic hydrocarbons in fly ash from fluidized bed combustion systems. Environ. Sci. Technol. 34, 2273-2279.

Lopareva-Pohu, A., Pourrut, B., Waterlot, C., Garçon, G., Bidar, G., Pruvot, C., Shirali, P., Douay, F., 2011. Assessment of fly ash-aided phytostabilisation of highly contaminated soils after an 8-year field trial. Part 1 . Influence on soil parameters and metal extractability. Sci. Total Environ. 409, 647-654.

Lopez-Ramon, M.V., Fontecha-Camara, M.A., Alvarez-Merino, M.A., MorenoCastilla, C., 2007. Removal of diuron and amitrol from water under static and dynamic conditions using activated carbon in form of fiber, cloth and grains. Water Res. 41, 2865-2870.

Lu, M.-C., Lin, C.-J., Chyan, J.-M., Liao, C.-H., 2005. Removal of 2,4-dinitrophenol from aqueous solution by coal fly ash. Fresen. Environ. Bull. 14, 526-530.

Majumdar, K., Singh, N., 2007. Effect of soil amendments on sorption and mobility of metribuzin in soils. Chemosphere 66, 630-637.

Malik, A., Thapliyal, A., 2009. Eco-friendly fly ash utilization: potential for land application. Crit. Rev. Environ. Sci. Technol. 39, 333-366.

Martens, D.C., 1971. Avilability of plant nutrients in fly ash. Compost. Sci. 12, 15-19.

Martens, D.C., Schnappinge, M.G., Doran, J.W., Mulford, F.W., 1970. Fly ash as a fertilizer. In: Faber, J.H., et al. (Eds.), Ash Utilization Inf. Circ. 8488. US Department of the Interior, Bureau of Mines, Washington, DC.

Mastral, A.M., Callen, M.S., 2000. A review on polycyclic aromatic hydrocarbon (PAH) emissions from energy generation. Environ. Sci. Technol. 34, 3051-3057.

Mastral, A.M., Callen, M.S., Mayoral, C., Galban, J., 1995. Polycyclic aromatic hydrocarbon emissions from fluidized bed combustion of coal. Fuel 74, 1762-1766.

Mastral, A.M., Callen, M.S., Garcia, T., 2000. Toxic organic emissions from coal combustion. Fuel Process Technol. 67, 1-10.

Matsi, T., Keramidas, V., 1999. Fly ash application on two acid soils and its effect on soil salinity, pH, B, P and on ryegrass growth and composition. Environ. Pollut. 104, 107-112.

Mench, M., Renella, G., Gelsomino, A., Landi, L., Nannipieri, P., 2006. Biochemical parameters and bacterial species richness in soils contaminated by sludgeborne metals and remediated with inorganic soil amendments. Environ. Pollut. 144, 24-31.

Mengel, K., Kirkby, E.A., 1987. Further Elements of Importance, fourth ed. Principles of Plant Nutrition International Potash Institute, Bern Switzerland, pp. 577-582 (Chapter 19).

Misra, M., Yang, K., Mehta, R.K., 1996. Application of fly ash in the agglomeration of reactive mine tailings. J. Hazard. Mater. 51, 181-192.

Mittra, B.N., Karmakar, S., Swain, D.K., Ghosh, B.C., 2005. Fly ash a potential source of soil amendment and a component of integrated plant nutrient supply system. Fuel 84, 1447-1451.

Neil, L.R., Rippey, B., 2002. The historical record of PAH, PCB, trace metal and fly-ash particle deposition at a remote lake in north-west Scotland. Environ. Pollut. 117, $121-132$.

Nyambura, M.G., Mugera, W.G., Felicia, P.L., Gathura, N.P., 2011. Carbonation of brine impacted fractionated coal fly ash: implications for $\mathrm{CO}_{2}$ sequestration. J. Environ. Manage. 92, 655-664.

Ohno, T., 1992. Neutralization of soil acidity and release of phosphorus and $\mathrm{K}$ by wood ash. J. Environ. Qual. 21, 433-438.

Ohno, T., Erich, M.S., 1990. Effect of wood ash application on soil pH and soil test nutrient levels. Agric. Ecosyst. Environ. 32, 223-239.

Oldeman, L.R., Vanengelen, V.W.P., 1993. A world soils and terrain digital database (SOTER)-an improved assessment of land resources. Geoderma 60, 309-325.

Page, A.L., Elseewi, A.A., Straughan, I.R., 1979. Physical and chemical properties of fly ash from coal-fired power plants, with reference to environmental impcts. Resid. Rev. 71, 83-120.

Pan, S.C., Lin, C.C., Tseng, D.H., 2003. Reusing sewage sludge ash as adsorbent for copper removal from wastewater. Resour. Conserv. Recyc. 39, 79-90.

Pandey, V.C., Singh, N., 2010. Impact of fly ash incorporation in soil systems. Agr. Ecosyst. Environ. 136, 16-27.

Panday, K.K., Prasad, G., Singh, V.N., 1984. Removal of Cr(VI) from aqueous solution by adsorption on fly ash wollastonite. J. Chem. Technol. Biotechnol. 34 (A), 367-374.

Panday, K.K., Prasad, G., Singh, V.N., 1985. Copper(II) removal from aqueous solutions by fly ash. Water Res. 19, 869-873.

Pandey, V.C., Abhilash, P.C., Upadhyay, R.N., Tewari, D.D., 2009. Application of fly ash on the growth performance and translocation of toxic heavy metals eithin Cajanus cajan L.: implication for safe utilization of fly ash for agricultural production. J. Hazard. Mater. 166, 255-259.
Pandey, V.C., Singh, C.K., Singh, R.P., Singh, B., 2012. Naturally growing Saccharum munja L. on the flyash lagoons: a potential ecological engineer for the revegetation and stabilization. Ecol. Eng. 40, 95-99.

Papandreou, A., Stournaras, C.J., Panias, D., 2007. Copper and cadmium adsorption on pellets made from fired coal fly ash. J. Hazard. Mater. 148, 538-547.

Pathan, S.M., Aylmore, L.A., Colmer, T.D., 2003. Soil properties and turf growth on a sandy soil amended with fly ash. Plant Soil 256, 103-114.

Patra, K.C., Rautray, T.R., Nayak, P., 2012a. Elemental analysis of coal and coal ash by PIXE technique. Appl. Radiat. Isot. 70, 612-616.

Patra, K.C., Rautray, T.R., Nayak, P., 2012b. Analysis of grains grown on fly ash treated soils. Appl. Radiat. Isot. 70, 1797-1802.

Pattanayak, J., Mondal, K., Mathew, S., Lalvani, S.B., 2000. A parametric evaluation of the removal of As (V) and As (III) by carbon based adsorbents. Carbon 38, 589-596.

Pehlivan, E., Cetin, S., 2007. The use of fly ash as a low cost, environmentally friendly alternative to activated carbon for the removal of heavy metals from aqueous solutions. Colloid Surf. A 298, 83-87.

Pisupati, S.V., Wasco, R.S., Scaroni, A.W., 2000. An investigation of polycyclic aromatic hydrocarbon emissions from pulverized coal combustion systems. J. Hazard. Mater. 74, 91-107.

Querol, X., Fernandez-Turiel, J.L., Lopez-Soler, A., 1995. Trace elements in coal and their behavior during combustion in a large power station. Fuel 74, 331-343.

Rao, M., Parwate, A.V., Bhole, A.G., Kadu, P.A., 2003. Performance of low-cost adsorbents for the removal of copper and lead. J Water Supply: Res Technol-AQUA 52, 49-58.

Ram, L.C., Masto, R.E., 2014. Fly ash for soil amelioration: a review on the influence of ash blending with inorganic and organic amendments. Earth Sci. Rev. 128, $52-74$.

Ram, L.C., Srivastava, N.K., Tripathi, R.C., Jha, S.K., Sinha, A.K., Manoharan, V., $2006 a$. Management of mine spoil for crop productivity with lignite fly ash and biological amendments. J. Environ. Manage. 79, 173-187.

Ram, L.C., Srivastava, N.K., Jha, S.K., Sinha, A.K., 2006b. Eco-friendly reclamation of mine spoil for agro-forestry through fly ash and biological amendments. In: Proceedings of 23rd Annual International Pittsburgh Coal Conference, pp. 1-25.

Ram, L.C., Srivastava, N.K., Jha, S.K., Sinha, A.K., Masto, R.E., Selvi, V.A., 2007. Management of lignite fly ash through its bulk use via biological amendments for improving the fertility and crop productivity of soil. Environ. Manage. 40, 438-452.

Rautaray, S.K., Ghosh, B.C., Mittra, B.N., 2003. Effect of fly ash, organic wastes and chemical fertilizers on yield, nutrient uptake, heavy metal content and residual fertility in a rice-mustard cropping sequence under acid lateritic soils. Bioresour. Technol. 90, 275-283.

Ricou, P., Lecuyer, I., Le Cloirec, P., 1999. Removal of $\mathrm{Cu}^{2+}, \mathrm{Zn}^{2+}$ and $\mathrm{Pb}^{2+}$ by adsorption onto fly ash and fly ash/lime mixing. Water Sci. Technol. 39, 239-247.

Riehl, F., Elsass, J., Duplay, F., Huber, M., Trautmann, M., 2010. Changes in soil properties in a fluvisol (calcaric) amended with coal fly ash. Geoderma 155 , 67-74.

Rose, N.L., Rippey, B., 2002. The historical record of PAH, PCB, trace metal and flyash particle deposition at a remote lake in north-west Scotland. Environ. Pollut. 117, 121-132.

Saarsalmi, A., Möalkönen, E., Piirainen, S., 2001. Effects of wood ash fertilization on forest soil chemical properties. Silva Fenn. 35, 355-368.

Sahu, S.K., Pandit, G.G., Sadasivan, S., 2004. Precipitation scavenging of polycyclic aromatic hydrocarbons in Mumbai, India. Sci. Total Environ. 318, 245-249.

Sahu, S.K., Bhangare, R.C., Ajmal, P.Y., Sharma, S., Pandit, G.G., Puranik, V.D., 2009 Characterization and quantification of persistent organic pollutants in fly ash from coal fueled thermal power stations in India. Microchem. J. 92, 92-96.

Sajwan, K.S., Ornes, W.H., Youngblood, T., 1995. The effect of fly ashy sewage sludge mixtures and application rates on biomass production. J. Environ. Sci. Health 30, 1327-1337.

Sajwan, K.S., Paramasivam, S., Alva, A.K., Adriano, D.C., Hooda, P.S., 2003. Assessing the feasibility of land application of fly ash, sewage sludge and their mixtures. Adv. Environ. Res. 8, 77-91.

Sakai, S., 1999. Substance flow approach for regionally based assessment of POPs. Presentation to UNEP Workshop, Geneva, available on UNEP website.

Schiemenz, K., Eichler-Lobermann, B., 2010. Biomass ashes and their phosphorus fertilizing effect on different crops. Nutr. Cycl. Agroecosyst. 87, 471-482.

Schiemenz, K., Kern, J., Paulsen, H.-M., Bachmann, S., Eichler-Löbermann, B., 2011. Phosphorus fertilizing effects of biomass ashes. In: Insam, H., Knapp, B.A. (Eds.), Recycling of Biomass Ashes. Springer Verlag, Heidelberg, pp. 17-31.

Schnaak, W., Kuchler, T., Kujawa, M., Henschel, K.-P., Subenbach, D., Donau, R., 1997. Organic contaminants in sewage sludge and their ecotoxicological significance in the agricultural utilization of sewage sludge. Chemosphere 35, 5-11.

Scotti, A., Silva, S., Botteschi, G., 1999. Effect of fly ash on the availability of Zn, Cu, Ni and Cd to chicory. Agr. Ecosyst. Environ. 72, 159-163.

Sen, A.K., De, A.K., 1987. Adsorption of mercury(II) by coal fly ash. Water Res. 21, 885-888.

Shaheen, S.M., Tsadilas, C.D., 2010. Sorption of cadmium and lead by acidic Alfisols as influenced by fly ash and sewage sludge application. Pedosphere 20, 436-445.

Shaheen, S.M., Tsadilas, C.D., 2013. Phosphorus sorption and availability to canola grown on an Alfisol amended with various soil amendments. Commun. Soil Sci. Plan. 44, 89-103. 
Shaheen, S.M., Shams, M.S., Elbehiry, F.A., Ibrahim, S.M., 2012a. Influence of stabilized biosolids application on soil properties and availability of phosphorus, copper and zinc. Appl. Environ. Soil Sci. http://dx.doi.org/10.1155/2012/817158.

Shaheen, S.M., Derbalah, A.S., Moghanm, F.S., 2012b. Removal of heavy metals from aqueous solution by zeolite in competitive sorption system. Int. J. Environ. Sci. Dev. 3, 362-367.

Shaheen, S.M., Eissa, F., Ghanem, K.M., Gamal, El-Din H., Al-Anany, F., 2013. Heavy metals removal from aqueous solutions and wastewaters by using various by products. J. Environ. Manage. 128, 514-521.

Sharma, P.K., Kumar, A., Joseph, P.E., 2008. Removal of atrazine from water by low cost adsorbents derived from agricultural and industrial wastes. Bull. Environ. Contam. Toxicol. 8, 461-464.

Shukla, K.N., Mishra, L.C., 1986. Effect of fly ash extract on growth and development of corn and soyabean seedling. Water Air Soil Pollut. 27, 155-167.

Siddique, R., 2010. Utilization of coal combustion by-products in sustainable construction materials. Resour. Conserv. RecyC. 54, 1060-1066.

Sikka, R., Kansal, B.D., 1995. Effect of fly ash application on yield and nutrient composition of rice, wheat and on $\mathrm{pH}$ and available nutrient status of soils. Bioresour. Technol. 51, 199-203.

Sims, J.T., Vasilas, B.L., Ghodrati, M., 1995. Evaluation of fly ash as a soil amendment for the Atlantic Coastal Plain. II. Soil chemical properties and crop growth. Water Air Soil Pollut. 81, 363-372.

Singh, A., Agrawal, S.B., 2010. Response of mung bean cultivars to fly ash: growth and yield. Ecotox. Environ. Safe 73, 1950-1958.

Singh, N., Raunaq, Singh, S.B., 2012. Effect of fly ash on sorption behavior of metribuzin in agricultural soils. J. Environ. Sci. Health B 47, 89-98.

Singh, L.P., Siddiqui, Z.A., 2003. Effects of fly ash and Helminthosporium oryzae on growth and yield of three cultivars of rice. Bioresour. Technol. 86, 73-78.

Singh, N., Raunaq, Singh, S.B., 2013a. Reduced downward mobility of metribuzin in fly ash-amended soils. J. Environ. Sci. Health B 48, 587-592.

Singh, N., Raunaq, Singh, S.B., 2013b. Effect of fly ash amendment on persistence of metribuzin in soils. J. Environ. Sci. Health. B 48, 108-113.

Singh, S.N., Kulshreshtha, K., Ahmad, K.J., 1997. Impact of fly ash soil amendment on seed germination, seedling growth and metal composition of Vicia faba L. Ecol, Eng. 9, 203-208.

Singh, A., Sharma, R.K., Agrawal, S.B., 2008. Effects of fly ash incorporation on heavy metal accumulation, growth and yield responses of Beta vulgaris plants. Bioresour. Technol. 99, 7200-7207.

Singh, R.P., Gupta, A.K., Ibrahim, M.A., Mittad, A.K., 2010. Coal fly ash utilization in agriculture: its potential benefits and risks. Rev. Environ. Sci. Biotechnol. 9, $345-358$.

Sinha, S., Gupta, A.K., 2005. Translocation of metals from fly ash amended soil in the plant of Seabania cannabina L. Ritz: effect on antioxidants. Chemosphere 61, 1204-1214.

Skousen, J., Yang, J.E., Lee, J., Ziemkiewicz, P., 2013. Review of fly ash as a soil amendment. Geosyst. Eng. 16, 249-256.

Sloss, L., Smith, I.M., 1993. Organic Compounds from Coal Utilisation. IEACR/63. IEA Coal Research, London.

Stevens, J.L., Northcott, G.L., Stern, G.A., Tomy, G.T., Jones, K.C., 2003. PAHs, PCBs, PCNs, organochlorine pesticides, synthetic musks, and polychlorinated n-alkanes in U.K. sewage sludge: survey results and implications. Environ. Sci. Technol. 37, 462-467.

Su, D.C., Wong, J.W.C., 2004. Chemical speciation and phytoavailability of Zn, Cu, Ni and $\mathrm{Cd}$ in soil amended with fly ash-stabilized sewage sludge. Environ. Int. 29, 895-900.

Thind, H.S., Singh, Y., Singh, B., Singh, V., Sharma, S., Vashistha, M., Singh, G., 2012. Land application of rice husk ash, bagasse ash and coal fly ash: effects on crop productivity and nutrient uptake in rice-wheat system on an alkaline loamy sand. Field Crop. Res. 135, 137-144.

Tolle, D.A., Arthrur, M.F., 1983. Microcosm/field comparison of trace element uptake in crops grown in fly ash amended soil. Sci. Total Environ. 31, 243-261.

Tripathi, R.C., Masto, R.E., Ram, L.C., 2009. Bulk use of pond ash for cultivation of wheat-maize-eggplant crops in sequence on a fallow land. Resour. Conserv. Recyc. 54, 134-139.
Tsadilas, C.D., Samaras, V., Kazai, P., Sgouras, J., 2002. Fly ash and sewage sludge application on an acid soil and their influence on some soil properties and wheat biomass production. In: Proceedings of the 2002, vol. III. International Soil Conservation Organization, Beijing, China, pp. 118-123. May 26-31, 2002.

Tsadilas, C.D., Shaheen, S.M., Samaras, V., 2009a. Influence of coal fly ash application individually and mixing with sewage sludge on wheat growth and soil chemical properties under field conditions. In: 15th International Symposium on Environmental Pollution and its Impact on Life in the Mediterranean Region. October, 7-11, Bari, Italy.p. 145.

Tsadilas, C.D., Shaheen, S.M., Samaras, V., Tang, S., Hu, Z., 2009b. Agricultural use of fly ash and sewage sludge and its impact on soil properties and bioavailability of heavy metals to wheat. In: 11th International symposium on soil and plant analysis, July, 20-24, Santa Rosa, California, USA. p. 131.

Tsadilas, C.D., Shaheen, S.M., Gizas, D., Samaras, V., Hu, Z., 2009c. Influence of fly ash application on copper and zinc sorption by acidic soil amended with biosolids. Commun. Soil Sci. Plant Anal. 40, 168-179.

Ukwattage, N.L., Ranjith, P.G., Bouazza, M., 2013. The use of coal combustion fly ash as a soil amendment in agricultural lands (with comments on its potential to improve food security and sequester carbon). Fuel 109, 400-408.

Ulery, A.L., Graham, R.C., Amrhein, C., 1993. Wood-ash composition and soil pH following intense burning. Soil Sci. 156, 358-364.

United State Environmental Protection Agency; USEPA, 1992. Suspect chemical sourcebook, source list 10. In: Clansky, K.B., Bathesda, M.D. (Eds.), EPA Human Health Assessment Group Substances. Roytech Publications Inc.

Vom Berg, W., 1998. Utilization of fly ash in Europe. In: Verma, C.V.J., Lal, P.K., Kumar, V., Lal, R., Krishnamurti, R. (Eds.), Proc. of Int. Conf. on Fly Ash Disposal and Utilization, vol. I. Central Board of Irrigation and Power, New Delhi, India, pp. 8-14.

Wang, S., Wu, H., 2006. Environmental-benign utilization of fly ash as low-cost adsorbents. J. Hazard. Mater. 136, 482-501.

Wang, S., Li, L., Zhu, Z., 2007. Solid-state conversion of fly ash to effective adsorbents for Cu removal from wastewater. J. Hazard. Mater. 39, 254-259.

Wang, C., Chang, D., Han, X., Zhang, M., 2013. Removal of Cr(VI) from aqueous solution by flocculant with the capacity of reduction and chelation. J. Hazard. Mater. 248-249, 115-121.

Warren, C.J., Dudas, M.J., 1984. Weathering processes in relation to leachate properties of alkaline fly ash. J. Environ. Qual. 13, 530-538.

Weinstein, L.H., Osmeloski, J.F., Rutzke, M., Beers, A.O., McCahan, J.B., Bache, C.A., Lisk, D.J., 1989. Elemental analysis of grasses and legumes growing on soil covering coal fly ash landfill sites. J. Food Saf. 9, 291-300.

Weng, C.H., Huang, C.P., 1994. Treatment of metal industrial wastewater by fly ash and cement fixation. J. Environ. Eng. 120, 1470-1487.

Weng, C.H., Huang, C.P., 2004. Adsorption characteristics of $\mathrm{Zn}$ from dilute aqueous solution by fly ash. Colloid. Surf. A: Physicochem. Eng. Asp. 247, 137-143.

Wilson, S.C., Alcock, R.E., Sewart, A.P., Jones, K.C., 1997. Organic chemicals in the environment: persistence of organic contaminants in sewage sludge-amended soil: a field experiment. J. Environ. Qual. 26, 1467-1477.

Weng, C.H., Huang, C.P., 1990. Removal of trace heavy metals by adsorption on fly ash. In: Proceedings of the 1990 ASCE Environmental Engineering Specialty Conference, pp. 923-924. Arlington: VA.

Wong, M.H., Wong, J.W.C., 1986. Effcts of fly ash on soil microbial activity. Environ. Pollut. 40, 127-144.

Xenidis, A., Mylona, E., Paspaliaris, I., 2002. Potential use of lignite fly ash for the control of acid generation from sulphidic wastes. Waste Manag. 22, 631-641.

Yadava, K.P., Tyagi, B.S., Panday, K.K., Singh, V.N., 1987. Fly ash for the treatment of Cd(II) rich effluents. Environ. Technol. Lett. 8, 225-234.

Yunusa, I.A.M., Eamus, D., De Silva, D.L., Murray, B.R., Burchett, M.D., Skilbeck, G.C., et al., 2006. Fly ash: an exploitable resource for management of Australian agricultural soils. Fuel 85, 2337-2344.

Yunusa, I.A.M., Loganathan, P., Nissanka, S.P., Manoharan, V., Burchett, M.D., Skilbeck, C., Derek Eamus, D., 2012. Application of coal fly ash in agriculture: a strategic perspective. Crit. Rev. Environ. Sci. Technol. 42, 559-600. 